\title{
Persistent CaMKII Activation Mediates Learning-Induced Long-Lasting Enhancement of Synaptic Inhibition
}

\author{
Sourav Ghosh, Iris Reuveni, Raphael Lamprecht, and Edi Barkai \\ Sagol Department of Neurobiology, Faculty of Natural Sciences, University of Haifa, Haifa 31905, Israel
}

Training rats in a particularly difficult olfactory-discrimination task results in acquisition of high skill to perform the task superbly, termed "rule learning" or "learning set." Such complex learning results in enhanced intrinsic neuronal excitability of piriform cortex pyramidal neurons, and in their excitatory synaptic interconnections. These changes, while subserving memory maintenance, must be counterbalanced by modifications that prevent overspreading of activity and uncontrolled synaptic strengthening. Indeed, we have previously shown that the average amplitude of $\mathrm{GABA}_{\mathrm{A}}$-mediated miniature IPSCs (mIPSCs) in these neurons is enhanced for several days after learning, an enhancement mediated via a postsynaptic mechanism. To unravel the molecular mechanism of this long-term inhibition enhancement, we tested the role of key second-messenger systems in maintaining such long-lasting modulation. The calcium/ calmodulin-dependent kinase II (CaMKII) blocker, KN93, significantly reduced the average mIPSC amplitude in neurons from trained rats only to the average pretraining level. A similar effect was obtained by the CaMKII peptide inhibitor, tatCN21. Such reduction resulted from decreased single-channel conductance and not in the number of activated channels. The PKC inhibitor, GF109203X, reduced the average mIPSC amplitude in neurons from naive, pseudo-trained, and trained animals, and the difference between the trained and control groups remained. Such reduction resulted from a decrease in the number of activated channels. The PKA inhibitor H89 dihydrochloride did not affect the average mIPSC amplitude in neurons from any of the three groups. We conclude that learning-induced enhancement of $\mathrm{GABA}_{\mathrm{A}}$-mediated synaptic inhibition is maintained by persistent CaMKII activation.

Key words: olfactory learning; piriform cortex; pyramidal neurons; second messenger; synaptic inhibition

\section{Introduction}

Rats that are trained in a particularly difficult olfactory discrimination (OD) task demonstrate a dramatic increase in their capability to acquire memories of new odors, once they learn the first discrimination task ("rule learning"; Saar et al., 1998, 1999). Rule learning is accompanied by a series of cellular modifications in layer II pyramidal neurons of the piriform cortex. Long-term enhancement occurs in the three components controlling neuronal activation, as follows: the excitatory synaptic drive mediated by glutamate receptors (Saar et al., 1999, 2002, 2012; Knafo et al., 2005), intrinsic neuronal excitability (Saar et al., 1998, 2001; Cohen-Matsliah et al., 2007); and $\mathrm{GABA}_{\mathrm{A}}$ receptor-mediated synaptic inhibition (Brosh and Barkai, 2009; Saar et al., 2012; Kfir et al., 2014). Such enhancement of synaptic inhibition is required to compensate for overexcitability, which may lead to epileptiform discharge (Golomb and Ermentrout, 2002; Hasselmo and Barkai, 1995).

Activity-induced enhancement of inhibitory synaptic transmission has been shown in several brain regions of the mamma-

\footnotetext{
Received May 26, 2014; revised 0ct. 1, 2014; accepted 0ct. 1, 2014.

Author contributions: I.R., R.L., and E.B. designed research; S.G. performed research; S.G. and I.R. analyzed data; S.G., I.R., R.L., and E.B. wrote the paper.

This work was supported by grants from the Israel Science Foundation to E.B.

Correspondence should be addressed to Dr. Edi Barkai, Department of Biology, Faculty of Sciences, Haifa University, Haifa 31905, Israel. E-mail: ebarkai@research.haifa.ac.il.

DOI:10.1523/JNEUROSCI.2123-14.2015

Copyright $\odot 2015$ the authors $\quad 0270-6474 / 15 / 350128-12 \$ 15.00 / 0$
}

lian brain (Grunze et al., 1996; Komatsu and Yoshimura, 2000; Holmgren and Zilberter, 2001; Scelfo et al., 2008). Both presynaptic (Ohba et al., 2005; McKay et al., 2013) and postsynaptic (Ohba et al., 2005; Fiumelli et al., 2005) mechanisms have been implicated in the process. Learning was also shown to trigger an increase in inhibitory synaptogenesis and in the GABA content of inhibitory synapses (Jasinska et al., 2010). Recently, it was shown that learning-induced network plasticity is induced via parvalbumin-expressing neurons (Donato et al., 2013). Also, prefrontal parvalbumin neuron network activity patterns were shown to be causally related to fear expression (Courtin et al., 2014).

OD learning-induced enhancement of $\mathrm{GABA}_{\mathrm{A}}$-mediated synaptic inhibition is maintained by a hyperpolarizing shift in the chloride reversal potential (Brosh and Barkai, 2009) and by postsynaptic modulation of $\mathrm{GABA}_{\mathrm{A}}$ receptor-mediated currents. These modifications are widely spread throughout the piriform cortex pyramidal neuronal cell population (Brosh et al., 2009; Saar et al., 2012). Our recent findings indicate that enhanced inhibition results from increased $\mathrm{GABA}_{\mathrm{A}}$ channel conductance rather than from increase in the number of channels (Reuveni et al., 2013). The mechanism by which such long-lasting enhanced synaptic inhibition is maintained is yet to be revealed.

Postsynaptic $\mathrm{GABA}_{\mathrm{A}}$ channel conductance has been shown to be affected by several key second-messenger systems, such as calcium/calmodulin-dependent protein kinase II (CaMKII), protein kinase $\mathrm{C}(\mathrm{PKC})$, and protein kinase $\mathrm{A}$ (PKA). These three 
A

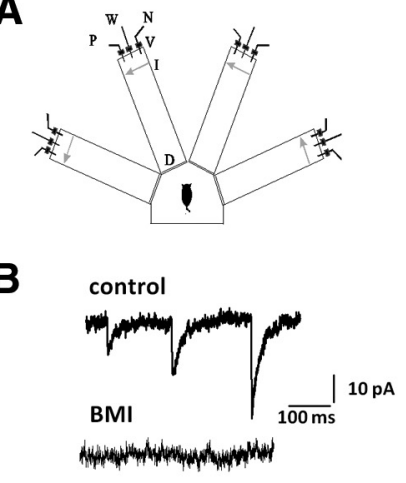

C

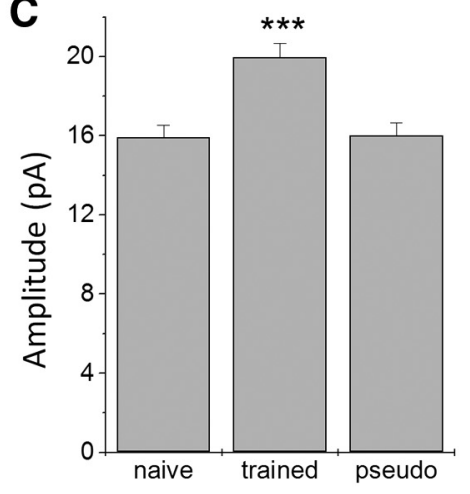

D

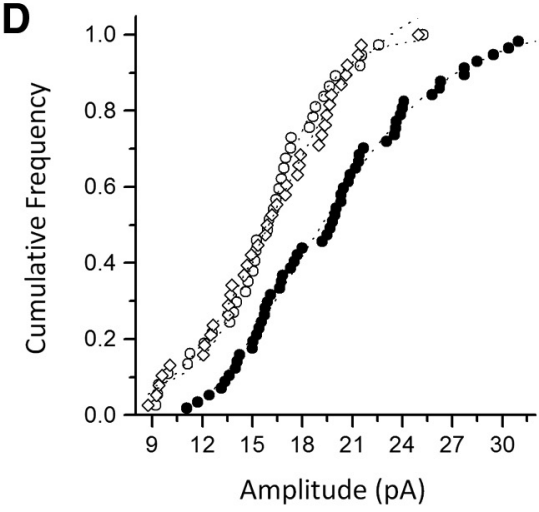

Figure 1. Rule learning-induced enhancement of spontaneous inhibitory events. $A$, Schematic description of the four-arm maze. Protocols for trained and pseudo-trained rats are similar: an electronic "start" command randomly opens two of eight valves (V), releasing a positive-cue odor (P) into one of the arms and a negative-cue odor (N) into another. Eight seconds later, the two corresponding guillotine doors (D) are lifted to allow the rat to enter the selected arms. Upon reaching the far end of an arm $(90 \mathrm{~cm} \mathrm{long})$, the rat body interrupts an infrared beam (I, arrow) and a drop of drinking water is released from a water hose (W) into a small drinking well (for a trained rat, only if the arm contains the positive-cue odor, for pseudo-trained rat, randomly). A trial ends when the rat interrupts a beam, or in $10 \mathrm{~s}$, if no beam is interrupted. A fan is operated for $15 \mathrm{~s}$ between trials, to remove odors. Each rat had 20 trials per day. B, Spontaneous inhibitory synaptic events recorded in a neuron from a trained rat at a holding potential of $-60 \mathrm{mV}$, in the presence of $1 \mu \mathrm{m} T T X, 20 \mu \mathrm{m}$ DNQX, and $50 \mu \mathrm{m}$ APV. Spontaneous activity was totally abolished in the presence of the $\mathrm{GABA}_{\mathrm{A}}$ blocker BMI $(20 \mu \mathrm{M})$. C, Average amplitude of spontaneous events in neurons from trained rats is significantly higher than in neurons from the two control groups. The average amplitude was calculated for each neuron from all spontaneous events. Values (mean \pm SE) represent the average of all cells in each group $\left({ }^{* * *} p<0.001\right)$. Data taken from 26 trained, 25 naive, and 19 pseudo-trained rats. $\boldsymbol{D}$, Cumulative frequency distributions of event amplitudes of the three groups. Each point represents the average event amplitude in a neuron. The average sIPSC amplitude appears to increase in most neurons in the trained group.

Table 1. Kinetics and basic membrane properties of IPSCs are not modified by learning

\begin{tabular}{lrrr}
\hline & \multicolumn{1}{c}{$\begin{array}{l}\text { Naive rats } \\
(n=36)\end{array}$} & \multicolumn{1}{c}{$\begin{array}{l}\text { Trained rats } \\
(n=57)\end{array}$} & \multicolumn{1}{c}{$\begin{array}{l}\text { Pseudo-trained rats } \\
(n=37)\end{array}$} \\
\hline IPSC rise time, ms & $2.59 \pm 0.51$ & $2.55 \pm 0.48$ & $2.57 \pm 0.60$ \\
IPSC decay time, ms & $16.22 \pm 3.64$ & $15.47 \pm 3.77$ & $14.95 \pm 3.45$ \\
Response to $-5 \mathrm{mV}$ step, pA & $12.50 \pm 6.25$ & $14.04 \pm 9.43$ & $11.48 \pm 5.82$ \\
rms noise, pA & $1.9 \pm 0.38$ & $2.02 \pm 0.41$ & $1.84 \pm 0.31$ \\
\hline
\end{tabular}

Data are the mean \pm SD. Rise time was measured for each detected event from baseline to peak. Decay time was measured for each detected event from peak to one third of the amplitude of the event. The basic membrane properties of neurons in which IPSCS were recorded are shown in the two bottom rows. The current response to a 100 $\mathrm{ms}$ voltage step of $-5 \mathrm{mV}$ was evoked at $0.16 \mathrm{~Hz}$. The rms noise was measured from $500 \mathrm{~ms}$ baseline recordings in which no spontaneous events were detected. No significant differences were found between groups in all the above parameters. $n$, Number of neurons.

kinases have phosphorylation sites on the $\mathrm{GABA}_{\mathrm{A}}$ receptor (McDonald and Moss, 1997) and have been shown to regulate its activity. CaMKII phosphorylation of the $\mathrm{GABA}_{\mathrm{A}}$ receptor was shown to regulate the expression of the cell surface receptors and their function (Houston et al., 2009; Saliba et al., 2012). PKCdependent phosphorylation was shown to enhance receptor surface stability (Abramian et al., 2010) and reduce its current (Krishek et al., 1994; Brandon et al., 2000). PKA can enhance or reduce inhibitory synaptic transmission by differential phosphorylation of two sites on $\mathrm{GABA}_{\mathrm{A}} \beta 3$ subunits (McDonald et al., 1998).

Here we study the role of these second messengers in maintaining long-lasting learning-induced enhancement of fast $\left(\mathrm{GABA}_{\mathrm{A}}\right.$-dependent) synaptic inhibition.

\section{Materials and Methods}

\section{Animal training}

Subjects and apparatus. Age-matched young adult (8 weeks old at the beginning of training) Sprague Dawley male rats were used. Before training, they were maintained on a $23.5 \mathrm{~h}$ water-deprivation schedule, with food available ad libitum. An olfactory discrimination training protocol was performed daily on each trained and pseudo-trained rat in a fourarm radial maze (Fig. 1A), as previously described (Saar et al., 1999, 2001) with commercial odors that are regularly used in the cosmetics and food industry, such as peach, lemon, orange, cinnamon, pine, rose, and straw- berry. Animal experiments were performed according to National Institutes of Health guidelines and were approved by the University of Haifa animal use committee.

Training. Olfactory training consisted of 20 trials per day for each rat, as previously described (Saar et al., 2001). In short, in each trial the rat had to choose between two odors (positive and negative cue) presented simultaneously. Rats designated to the trained group were rewarded with drinking water upon choosing the positive cue. Rats in the pseudotrained group were rewarded in a random fashion, upon choosing any odor. The criterion for learning was at least $80 \%$ positive-cue choices in the last 10 trials of a training day (Staubli et al., 1987; Saar et al., 1999, 2001). Rats in the naive group were water deprived, but not exposed to the maze.

Our previous studies show that the following two learning phases can be clearly distinguished (Saar et al., 1998, 1999; Zelcer et al., 2006): the first phase of rule learning, which usually requires $7-8 \mathrm{~d}$, in which rats develop a strategy for performing the odor discrimination task; and the second phase of enhanced learning capability, in which rats can learn new odors within 1-2 training days. In this study, rats were trained with one pair of odors until they reached the criterion for rule learning $(80 \%$ correct choices in the last 10 trials of a training day; Saar et al., 1998). They were subsequently allowed to rest, and after $4-5 \mathrm{~d}$ brain slices were prepared.

\section{Slice preparation and recordings}

Slice preparation. Three hundred micrometer coronal brain slices taken from the posterior piriform cortex were cut as previously described (Saar et al., 1998) and kept for at least $2 \mathrm{~h}$ in oxygenated $\left(95 \% \mathrm{O}_{2}\right.$ plus $\left.5 \% \mathrm{CO}_{2}\right)$ normal saline Ringer's solution (in mM: $\mathrm{NaCl} 124, \mathrm{KCl} 3, \mathrm{MgSO}_{4} 2$, $\mathrm{NaH}_{2} \mathrm{PO}_{4} 1.25, \mathrm{NaHCO}_{3} 26, \mathrm{CaCl}_{2}$ 2, and glucose 10). Then, slices were placed in a recording chamber under infrared differential interference contrast microscope, and perfused with Ringer's solution at $30^{\circ} \mathrm{C}$. Whole-cell voltage-clamp recordings were obtained from visually identified pyramidal neurons in layer II of the piriform cortex. All electrophysiological recordings were performed using Axopatch 1D (Molecular Devices), and the data were acquired using pClamp9 (Molecular Devices)

All experiments were performed in a blinded manner; the identity of the rat from which neurons were recorded (naive, trained, or pseudo-trained) was not known to the person conducting the experiments and measurements. One or two neurons were recorded from each rat. 


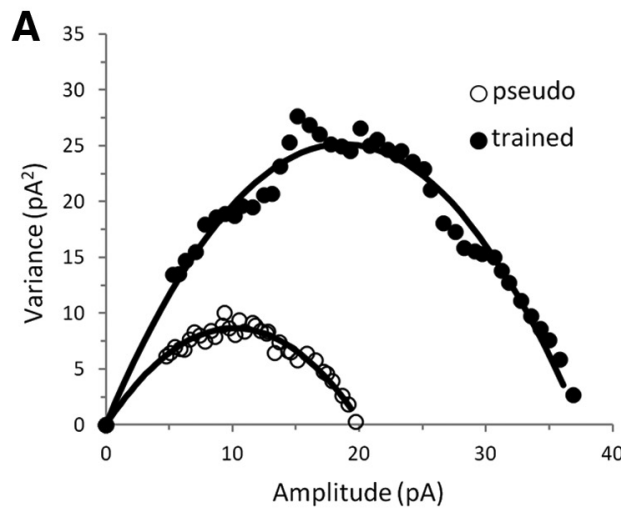

B

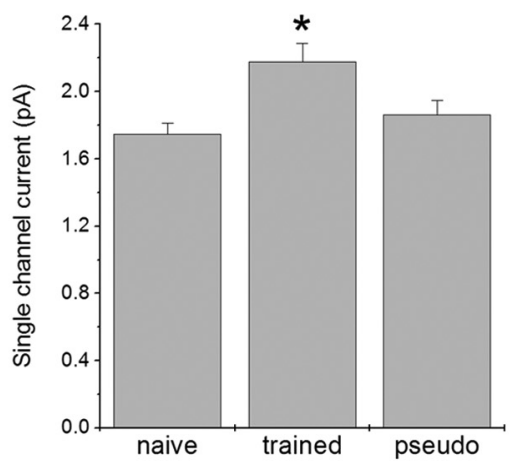

C

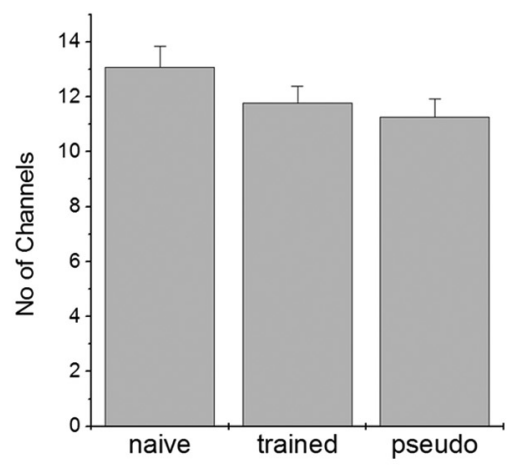

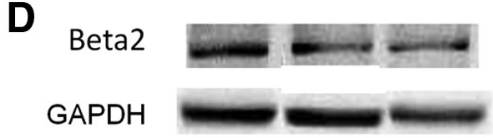

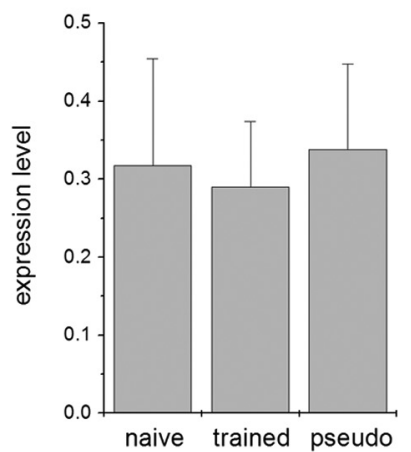

Beta3
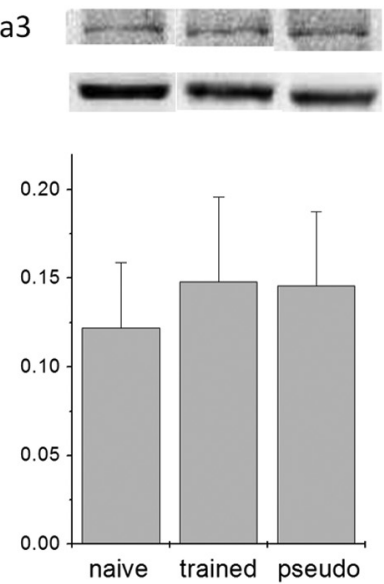

Gamma2
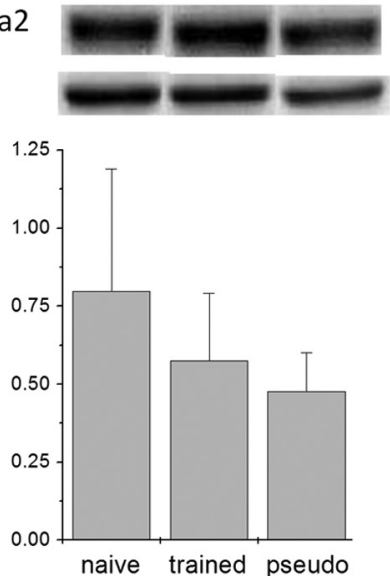

Figure 2. Learning-induced enhancement of synaptic inhibition results from increased single-channel conductance. $A$, Spontaneous inhibitory events were peak scaled and used for the NSFA (only events with a rise time of $<1.5 \mathrm{~ms}$ were used). Variance between these peak scaled events was calculated at different time points. The current-variance plot extracted from the peak scaled mIPSCs using the NSFA could be well fitted with the parabolic current-variance equation (see Materials and Methods), allowing the extraction of the average single-channel conductance and average number of active $\mathrm{GABA}_{\mathrm{A}}$ channels. Examples from a pseudo-trained cell and from a trained cell are shown. As is evident from the differences in the initial slope of the parabola, the single-channel conductance of the pseudo-trained cell was markedly lower compared with the conductance of the trained cell. $\boldsymbol{B}$, The average $G A B A_{A}$ single-channel conductance is enhanced after learning. Values represent the mean $\pm S E\left({ }^{*} p<0.05\right)$. Data taken from neurons in which $R>0.85 ; 22$ cells from 17 naive rats, 36 cells from 22 trained rats, and 27 cells from 14 pseudo-trained rats. $C$, The number of active $G A B A_{A}$ channels per event does not differ between groups. $D$, The expression level of GABA $\beta 2, G A B A \beta 3$, and GABA $\gamma 2$ receptors in the piriform cortex of rats from the three groups (trained, pseudo-trained, and naïve rats) was analyzed $4-5 \mathrm{~d}$ after training using Western blot. The expression of the three $\mathrm{GABA}_{A}$ receptor protein levels is not modified by learning. Top, Representative immunoblots for the three subunits receptor proteins prepared from the piriform cortex of naive, trained, and pseudo-trained rats. Bottom, Protein expression level of the three $G A B A_{A}$ receptors is not modified by olfactory learning. For each channel type, the protein level is normalized to the value of GAPDH. Summarized data are presented as the mean $0 D \pm S D, n=5$ for each group.

Miniature IPSC recordings. Layer II pyramidal neurons receive strong synaptic inhibition from several classes of GABAergic interneurons ( $\mathrm{Su}-$ zuki and Bekkers, 2007, 2010). To record $\mathrm{GABA}_{\mathrm{A}}$-mediated miniature IPSCs (mIPSCs), the recording electrode contained the following (in mM): 140 cesium chloride, 1 EGTA, $6 \mathrm{KCl}, 4 \mathrm{NaCl}, 2 \mathrm{MgCl}_{2}$, and 10 HEPES, pH 7.25 and $280 \mathrm{mOsm}$. In these conditions, the reversal potential of chloride is $\sim 0 \mathrm{mV}$, and thus strong $\mathrm{GABA}_{\mathrm{A}}$-mediated currents can be studied at a holding potential of $-60 \mathrm{mV}$ (Fig. 1B). The perfusion solution contained TTX $(1 \mu \mathrm{M})$, and also DNQX $(20 \mu \mathrm{M})$ and APV (50 $\mu \mathrm{M})$, to block glutamatergic synaptic transmission via AMPA receptors, thus allowing recording of pure IPSCs. Indeed, the mIPSCs were abolished by bicuculline methiodide (BMI; $20 \mu \mathrm{M}$ ) application (Fig. 1B). Recordings of spontaneous events were performed 15 min after membrane rupture and lasted for up to $1 \mathrm{~h}$. Each neuron was recorded at least $15 \mathrm{~min}$ previous to and $15 \mathrm{~min}$ after drug application. Each drug was applied for at least $20 \mathrm{~min}$ before recording its effect on the neuron. Drugs were applied using a gravity-based system, and the exchange solution estimated time is $<5 \mathrm{~min}$.

Drug application. All drugs were applied in the perfused Ringer's solution at the following concentrations: KN93 $10 \mu \mathrm{M}, \mathrm{KN} 9210 \mu \mathrm{M}$, GF109203X $10 \mu \mathrm{M}$, and H89 dihydrochloride $50 \mu \mathrm{M}$. The CaMKII cellpenetrating peptide inhibitor, tatCN21, and its scrambled inactive con- trol peptide, tatCtr (scrambled CN21; GL Biochem, Shanghai LTD), were applied via the Ringer's solution at a concentration of $5 \mu \mathrm{M}$ (Buard et al., 2010).

During the continuous recording, the current response to a $100 \mathrm{~ms}$ voltage step of $-5 \mathrm{mV}$ was monitored at $0.16 \mathrm{~Hz}$. A change in the response caused exclusion of the data.

For data analysis, each event was detected by eye and measured using the Mini "Analysis" software (Synaptosoft).

\section{Immunoblot analysis}

Rats from the three groups (naive, trained, and pseudo-trained) were killed $4-5 \mathrm{~d}$ after the learning set. The whole brain was immediately frozen in liquid nitrogen and kept at $-80^{\circ} \mathrm{C}$. Posterior piriform cortices from both the hemispheres were dissected out in a cryostat and kept at $-80^{\circ} \mathrm{C}$ until further use.

Tissues were homogenized in ice-cold lysis buffer (in mM: 10 HEPES, 2 EDTA, 2 EGTA, 0.5 DTT, and 4\% protease inhibitor cocktail; Roche) using a glass Teflon homogenizer. The homogenate was centrifuged at $10,000 \times g$ for $15 \mathrm{~min}$ at $4^{\circ} \mathrm{C}$, and the supernatant was collected. Five microliters of cell lysate from each sample was used for protein quantification using the Pierce BCA Protein Assay Kit (Thermo Scientific), and in the remaining volume of the lysate an equal volume of $2 \times$ sample 
A

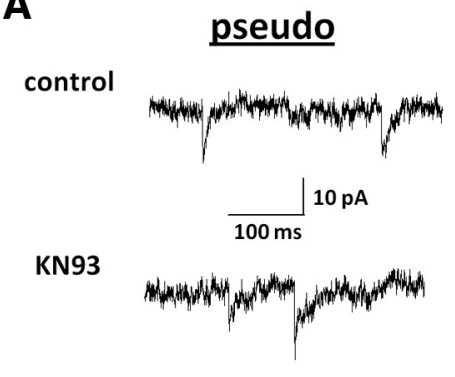

B
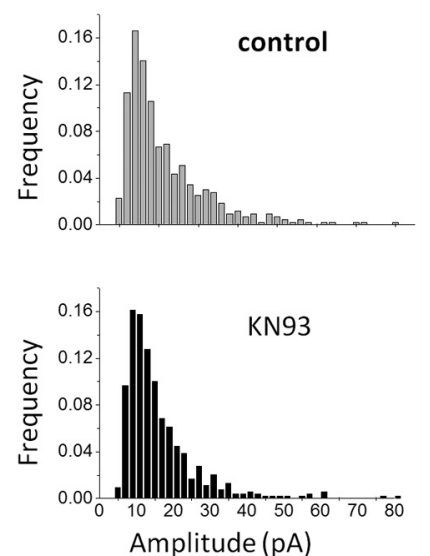

$\underline{\text { trained }}$
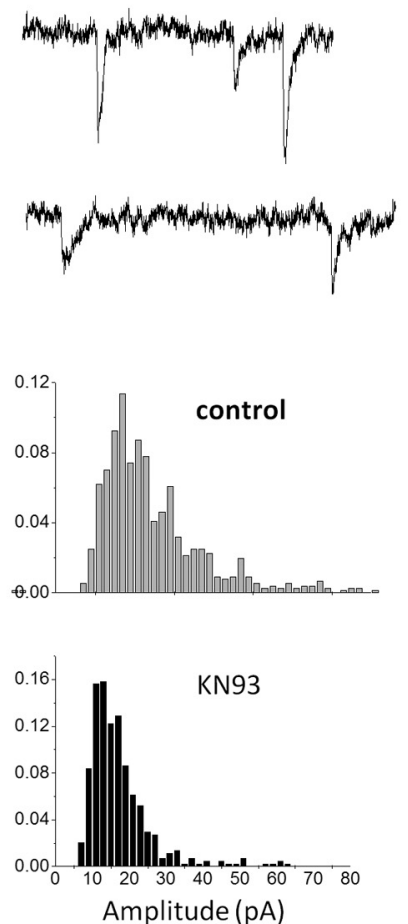

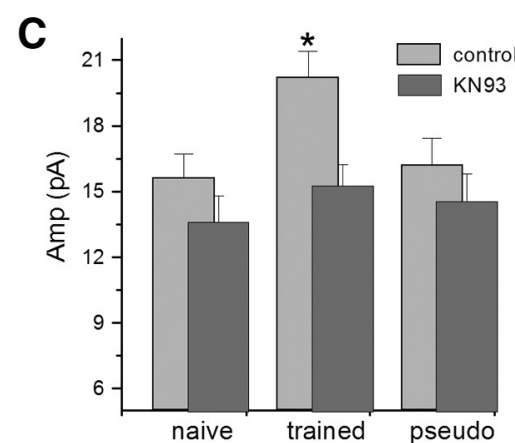

D

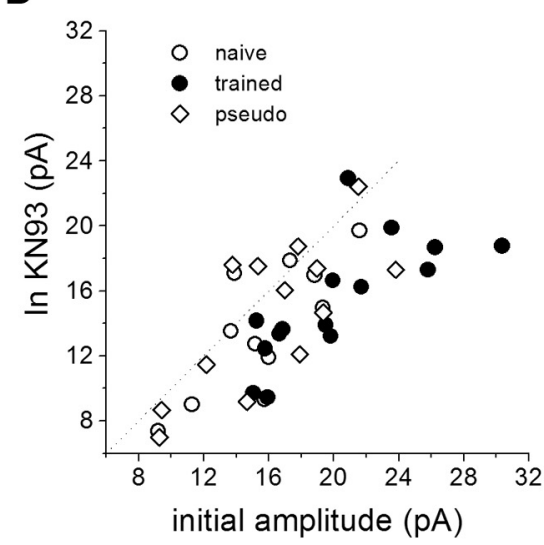

Figure 3. Learning-induced enhancement of spontaneous inhibitory events is CaMKII dependent. $A$, Spontaneous inhibitory events recorded from neurons from a pseudo-trained (left) and a trained (right) rat, before (top traces) and after (bottom traces) application of the CaMKII blocker KN93. While the drug has no apparent effect on the event amplitudes in the pseudo-trained rat neurons, high-amplitude events in the trained rat neurons were abolished. $\boldsymbol{B}$, Amplitude histograms of the two neurons recorded in $\boldsymbol{A}$. Note the large number of high-amplitude events in the trained rat neuron (top histogram, right) compared with the pseudo-trained rat neuron (top histogram, left). KN93 has little effect on the amplitude distribution in the pseudo-trained rat neuron (bottom histogram, left), while affecting strongly the trained rat neuron (bottom histogram, right). $C$, The average amplitude of the inhibitory synaptic events is significantly reduced in neurons from trained rats only after KN93 application $\left({ }^{*} p<0.05\right)$, as result of which the difference in the average amplitude between the groups disappear. Data taken from 10 naive, 9 trained, and 6 pseudo-trained rats. D, KN93 particularly affected neurons from trained rats.

buffer (5 mm Tris-HCl, pH 6.8, 10\% glycerol, 2.3\% SDS, and 5\% $\beta$-mercaptoethanol) was added, boiled at $100^{\circ} \mathrm{C}$ for $5 \mathrm{~min}$, vortexed, and stored at $-80^{\circ} \mathrm{C}$. For scaling, we first identify the linear scale of the different antibody-protein interaction, as defined by an increased protein concentration. Ten micrograms of tissue extracted from each sample were separated with $12 \%$ SDS-PAGE at $25 \mathrm{~mA}$ followed by blotting on to a $0.45 \mu \mathrm{m}$ nitrocellulose membrane at $350 \mathrm{~mA}$ for $1.5 \mathrm{~h}$. Blots were blocked in 5\% skim milk prepared in Tris-buffered saline Tween (TBST) for $2 \mathrm{~h}$ at room temperature followed by incubation with a primary antibody $(1: 1000$, rabbit anti-GABA $\beta 2$, Abcam; $1: 1000$, rabbit anti$\mathrm{GABA}_{\mathrm{A}} \beta 3$, Abcam; 1:1000, rabbit anti-GABA $\mathrm{A} \gamma$, Abcam; or 1:7500, rabbit GAPDH, Santa Cruz Biotechnology) overnight at $4^{\circ} \mathrm{C}$ in a shaker. The next day, blots were washed five times ( $5 \mathrm{~min}$ for each wash) with TBST, and then blots were incubated at room temperature for $1.5 \mathrm{~h}$ with secondary antibody (Jackson ImmunoResearch) coupled to horseradish peroxidase. After five more washings with TBST, proteins were visualized by enhanced chemiluminescence EZ-ECL (Biological Industries) and quantified using a CCD camera (XRS, Bio-Rad) and Quantity One software. We then calculated the ratio between each of the three $G_{A B A}$ subunit isoforms and GAPDH for each rat.

\section{Nonstationary fluctuation analysis}

Estimates of the average single-channel current and the average number of active channels were obtained using a peak scaled nonstationary fluctuation analysis (NSFA) of mIPSCs (Benke et al., 1998). NSFA was applied to the events that were electrotonically nearby $(10-90 \%$ with rise times $<1.5 \mathrm{~ms}$ ). Using Mini Analysis software (Synaptosoft Inc.), events ( $>150$ events per cell) were scaled and aligned by their peak; and their decay phase was divided into 30 bins, and within each bin the variance around the scaled average was computed. The single-channel current (i) and the number of channels $(N)$ were calculated (using Mini Analysis software) by fitting the theoretical relationship between the peak scaled variance $\left(\sigma^{2}\right)$ and the peak scaled current amplitude $(I)$ after subtraction of the background variance $\left(\sigma_{\mathrm{b}}^{2}\right)$, as follows:

$$
\sigma^{2}(t)=i \cdot I(t)-I(t)^{2} / N+\sigma_{b}^{2}
$$

Only cells in which the fitting of the equation yielded an $R>0.85$ were incorporated in the analysis.

\section{Statistical analysis}

Between groups, comparisons were performed using one-way ANOVA, and post hoc multiple nondirectional $t$ tests were then applied to make comparisons between each two groups. A paired $t$ test was used to examine the effect of drug application of each tested cell. Values throughout the text are presented as the mean \pm SD. Data in graphs are presented as mean $\pm \mathrm{SE}$.

\section{Results}

$\mathrm{GABA}_{\mathrm{A}}$-mediated mIPSCs were recorded from layer II pyramidal neurons $4-5 \mathrm{~d}$ after rule learning (Fig. $1 B$ ). As previously reported (Saar et al., 2012), olfactory discrimination learning induced a strong increase in the average amplitude of miniature events. The average mIPSC amplitude in neurons from trained rats $(20.0 \pm 5.3 \mathrm{pA}, n=57$ neurons taken from 26 rats $)$ was significantly $\left(F_{(2,129)}=12.39, p<0.001\right)$ higher compared with the average value in neurons from pseudo-trained rats $(16.0 \pm$ $4.0 \mathrm{pA}, n=37$ neurons taken from 19 rats) or naive rats $(15.9 \pm$ $3.8 \mathrm{pA}, n=36$ neurons taken from 25 rats; Fig. $1 C)$. 
A

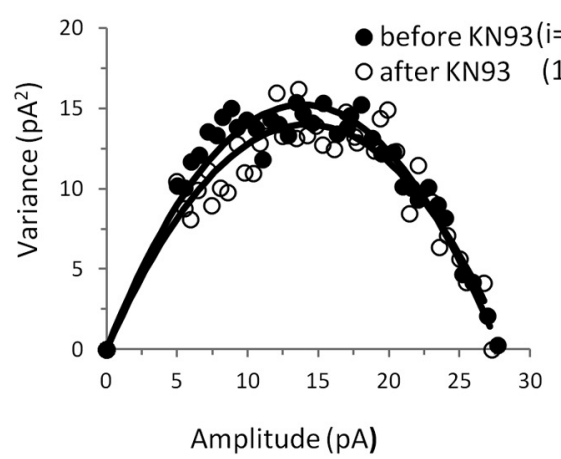

B

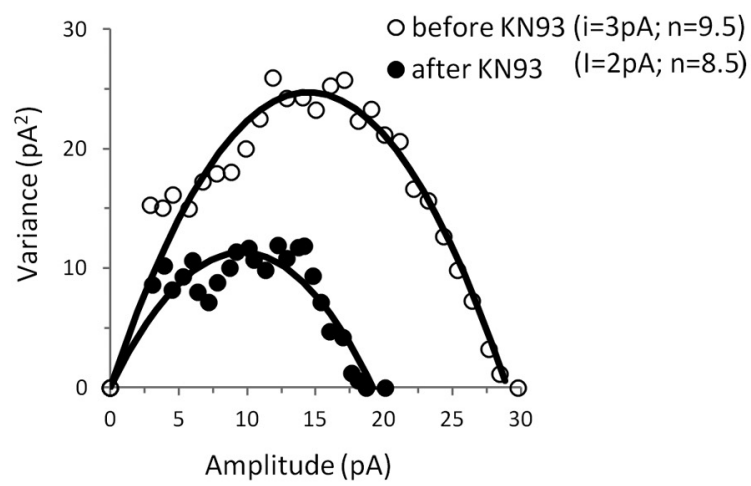

C

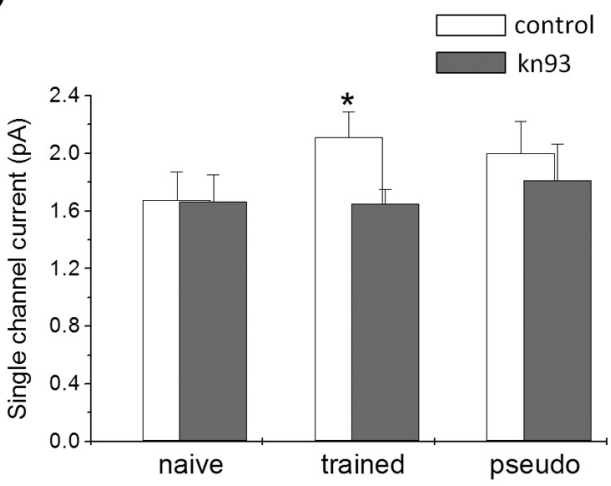

D

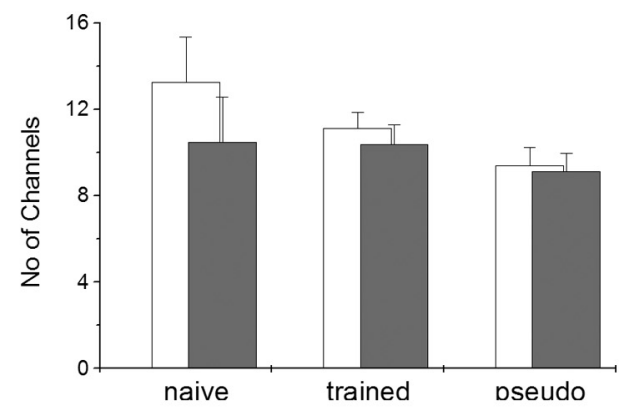

Figure 4. CaMKII reduces the single $\mathrm{GABA}_{\mathrm{A}}$ channel conductance in neurons from trained rats only. $\boldsymbol{A}, \boldsymbol{B}$, Current-variance plot extracted from the peak scaled mIPSCs before and after KN93 application. Examples from a pseudo-trained rat cell $(\boldsymbol{A})$ and a trained rat cell $(\boldsymbol{B})$ are shown. As evident from the initial slope of the parabola, KN93 reduced the single-channel current only in the trained neuron. $C$, The average $\mathrm{GABA}_{\mathrm{A}}$ single-channel conductance is significantly reduced after drug application only for neurons from trained rats. Values represent the mean $\pm \mathrm{SE}\left({ }^{*} p<0.05\right)$. $D$, The average number of active $G_{A B A}$ channels per event is not modified by drug application in the three groups. Average values were calculated using 7 cells taken from 6 naive rats, 14 cells taken from 8 trained rats, and 9 cells taken from 5 pseudo-trained rats.

As shown in Table 1, the average rise time and decay time did not differ among the naive, trained, and pseudo-trained groups. The rms noise was similar in all of the recordings. Also, cells from the three groups did not differ in their response to the standard negative pulse.

The increase in the average amplitude of mIPSCs was apparent throughout the neuronal cell population (Fig. 1D), as previously observed (Saar et al., 2012). Such learning-induced enhancement in the average amplitude of the spontaneous responses was not accompanied by modulation of the MIPSCs frequency $(120 \pm 61.1$ events/min in neurons form trained rats, compared with $94.6 \pm 53.4$ events/min in naive rats and $99.1 \pm$ 49.2 events/min in pseudo-trained rats).

Thus, OD learning results in long-term enhancement, with an average $25 \%$ increase in the amplitude $\mathrm{GABA}_{\mathrm{A}}$ receptormediated spontaneous inhibitory events, with no significant effect on the frequency of events. These results are similar to data presented in our earlier study (Saar et al., 2012).

\section{Learning-induced enhancement of inhibitory synaptic transmission is mediated by an increase in the $\mathrm{GABA}_{\mathrm{A}}$ channel conductance}

To explore whether the increase in the amplitude of miniature synaptic event results from increased single-channel conductance or an increased number of receptors, we applied a widely used method that exploits the variability in event shape (NSFA; Benke et al., 1998; Lüthi et al., 2004; Ling et al., 2006; Reuveni et al., 2013; Studniarczyk et al., 2013) to calculate both the average single-channel current and the average number of active $\mathrm{GABA}_{\mathrm{A}}$ channels in each cell (Fig. $2 A$; see also Materials and Methods). The average calculated single-channel current in the neurons from trained rats $(2.18 \pm 0.65 \mathrm{pA}, n=36)$ was significantly higher $\left(F_{(2,83)}=5.55, p<0.05\right)$ than the average values in naive rats $(1.75 \pm 0.29 \mathrm{pA}, n=22)$ and pseudo-trained rats $(1.86 \pm$ $0.44 \mathrm{pA}, n=26)$. The average calculated single-channel currents in neurons from the pseudo-trained and naive rats were not significantly different (Fig. 2B). Such an increase, with an average value of $21 \%$, resembles the learning-induced increase in amplitude of the synaptic events. In contrast, the calculated average number of active channels (Fig. 2C) did not differ between groups (11.8 \pm 3.7 for neurons from trained rats, $11.3 \pm 3.4$ for neurons from pseudo-trained rats, and $13.1 \pm 3.4$ for neurons naive rats). These results confirm our previous findings, which were obtained with a significantly smaller population of neurons (Reuveni et al., 2013).

To further examine the possibility that learning is accompanied by an increased number of $\mathrm{GABA}_{\mathrm{A}}$ receptors, we examined the protein expression level of the $\mathrm{GABA}_{\mathrm{A}} \beta 2, \mathrm{GABA}_{\mathrm{A}} \beta 3$, and $\mathrm{GABA}_{\mathrm{A}} \gamma 2$ subunits. We focused on these subunits because they could be affected by CaMKII phosphorylation (see below; Houston et al., 2009). We found that the expression level of the three subunits is not modified after learning (Fig. 2D), further indicating that the number of $\mathrm{GABA}_{\mathrm{A}}$ channels is not modified after learning. 
A

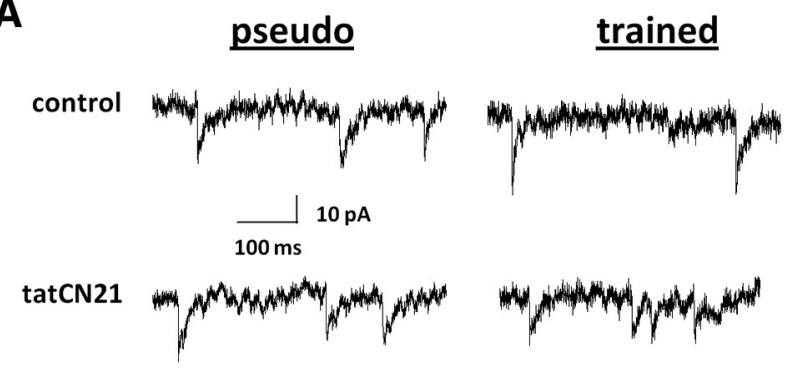

B
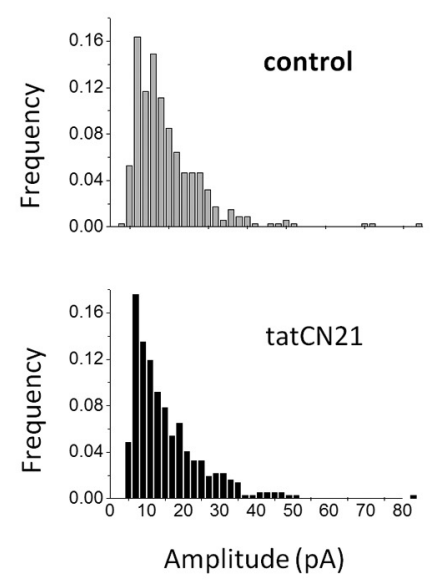
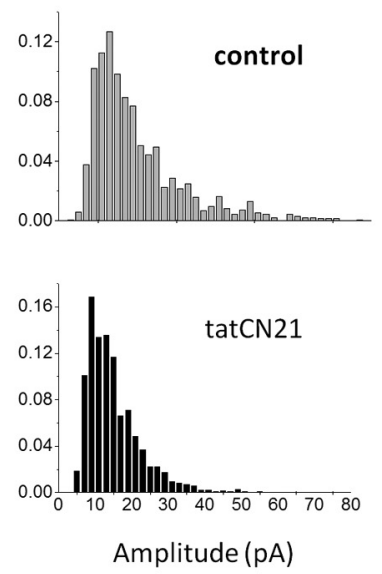

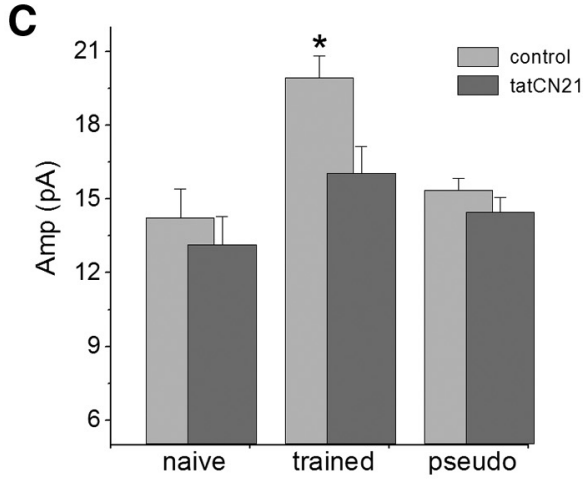

D

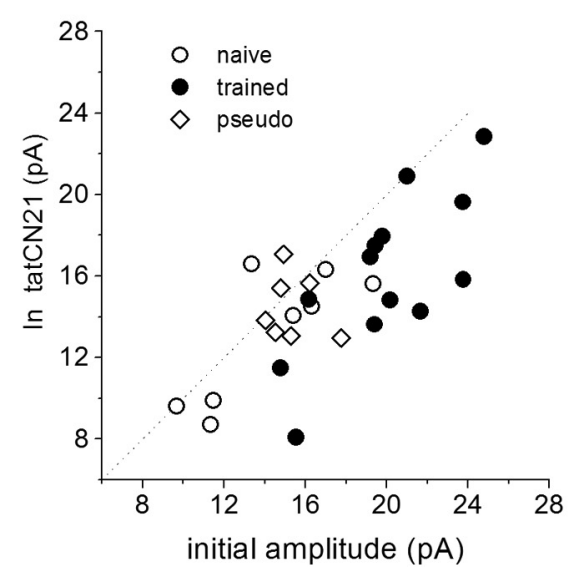

Figure 5. Learning-induced enhancement of spontaneous inhibitory events is abolished in the presence of the peptide inhibitor tatCN21. $\boldsymbol{A}$, Spontaneous inhibitory events recorded from a pseudo-trained (left) and a trained (right) neuron, before (top traces) and after (bottom traces) application of the peptide inhibitor tatCN21. While tatCN21 has no apparent effect on the event amplitudes in the pseudo-trained rat neurons, high-amplitude events in the trained rat neurons were abolished. $\boldsymbol{B}$, Amplitude histograms of the two neurons recorded in $\boldsymbol{A}$. Note the large number of high-amplitude events in the trained rat neuron (top histogram, right) compared with the pseudo-trained rat neuron (top histogram, left). tatCN21 has little effect on the amplitude distribution in the pseudo-trained neuron (bottom histogram, left), while strongly affecting the trained neuron (bottom histogram, right). $\boldsymbol{C}$, The average amplitude of the inhibitory synaptic events is significantly reduced in neurons from trained rats only after tatCN21 application ( ${ }^{*} p<0.05$ ), as result of which the difference in the average amplitude between the groups disappears. Data taken from five naive, eight trained, and four pseudo-trained rats. $\boldsymbol{D}$, tatCN21 affected particularly neurons from trained rats.

These data lend further support to the notion that the increase in amplitude of the miniature inhibitory events after learning is mediated by the modulation of the channel conductance. We thus hypothesized that such long-lasting enhancement is maintained by persistent activation of key second-messenger systems, which are known to have key roles in learning-relevant synaptic enhancement.

\section{Long-lasting enhancement of synaptic inhibition is} dependent on persistent CaMKII activation

Application of the CaMKII blocker KN93 $(10 \mu \mathrm{M})$ significantly reduced $\left(t_{(14)}=5.82, p<0.05\right)$ the average amplitude of the spontaneous inhibitory response only in neurons from trained rats (Fig. 3A). In neurons from trained rats, the average value of the mIPSCs was reduced from $19.8 \pm 4.5$ to $14.8+3.9 \mathrm{pA}(n=$ 15). In sharp contrast, the drug had no effect on neurons from naive animals ( $15.5 \pm 3.6 \mathrm{pA}$ in control conditions, $14.2 \pm 3.8 \mathrm{pA}$ in the KN93; $n=11)$ and from pseudo-trained rats (15.6 \pm 3.9 pA in control conditions, $14.4 \pm 4.7$ in KN93; $n=13$ ). As a result, the difference in the average mIPSC observed in the control groups was abolished after KN93 treatment (Fig. 3A-C). The effect of the CaMKII blocker was most pronounced in neurons from trained rats (Fig. 3D). The inactive drug form KN92 (10 $\mu \mathrm{M})$ had no effect on the neurons from the three groups [from $18.2 \pm 5.5$ to $17.5 \pm 6.6 \mathrm{pA}(n=16)$ in trained rats; from $14.8 \pm$
5.4 to $13.4 \pm 4.9 \mathrm{pA}(n=5)$ in naive rats; and from $14.4 \pm 2.6$ to $14.0 \pm 2.1 \mathrm{pA}(n=6)$ in pseudo-trained rats].

NSFA shows that such reduction in the average number of mIPSCs in neurons from trained rats is mediated by reduction of the average single-channel conductance (Fig. 4A, $B$ ); KN93 reduced the single-channel conductance significantly $\left(_{(28)}=5.35\right.$, $p<0.05$ ) in neurons from trained rats (from $2.1 \pm 0.65$ to $1.65 \pm$ $0.33 \mathrm{pA}, n=14$ ), while it had no effect on neurons from naive rats (from $1.67 \pm 0.53$ to $1.67+0.48 \mathrm{pA}, n=7$ ) and pseudo-trained rats (from $2.0 \pm 0.66$ to $1.81+0.66 \mathrm{pA}, n=9$ ). Subsequently, the differences in the average single-channel conductance among the groups disappeared (Fig. $4 \mathrm{C}$ ). In contrast, the average change in the number of channels activated by a spontaneous events was not affected by the drug application in neurons from the three groups [from $11.2 \pm 2.8$ to $10.4 \pm 3.1(n=14)$ in trained rats; from $13.3 \pm 5.5$ to $10.5 \pm 5.4(n=7)$ in naive rats; and from $9.4 \pm 2.5$ to $9.1 \pm 2.2(n=9)$ in pseudo-trained rats; Fig. $4 D]$.

To further examine whether this effect is indeed due to blocking of CaMKII, we applied the cell-penetrating peptide inhibitor tatCN21 (5 $\mu \mathrm{M}$; Buard et al., 2010; Yang et al., 2013). The peptide application significantly reduced $\left(t_{(26)}=5.35, p<0.05\right)$ the average amplitude of the spontaneous inhibitory response in neurons from trained rats only (Fig. 5A). In neurons from trained rats, the average value of the mIPSCs was reduced from $20.0 \pm 3.3$ to $16.0 \pm 3.9 \mathrm{pA}(n=13)$. The peptide had no effect on neurons 
A

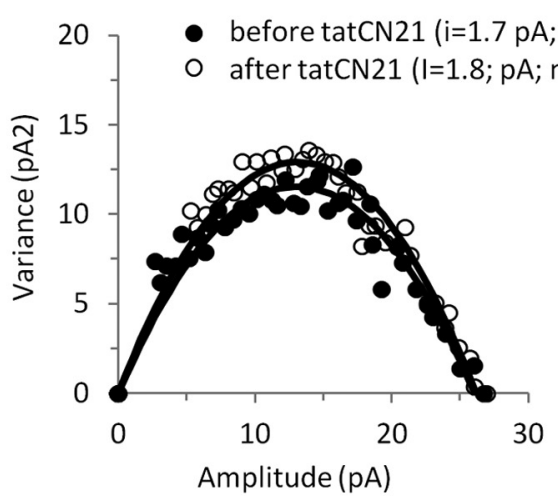

B

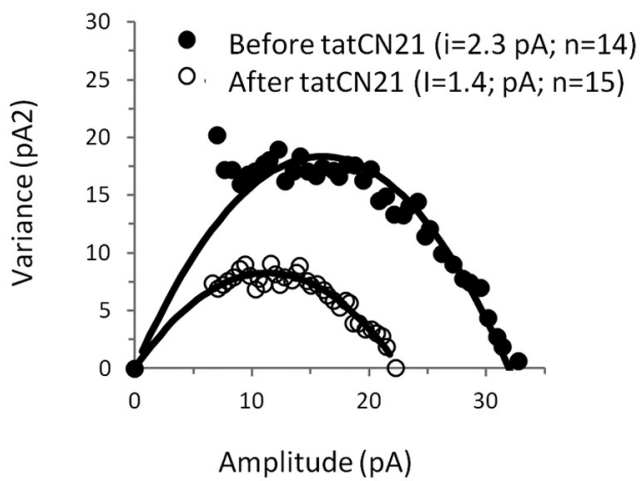

C

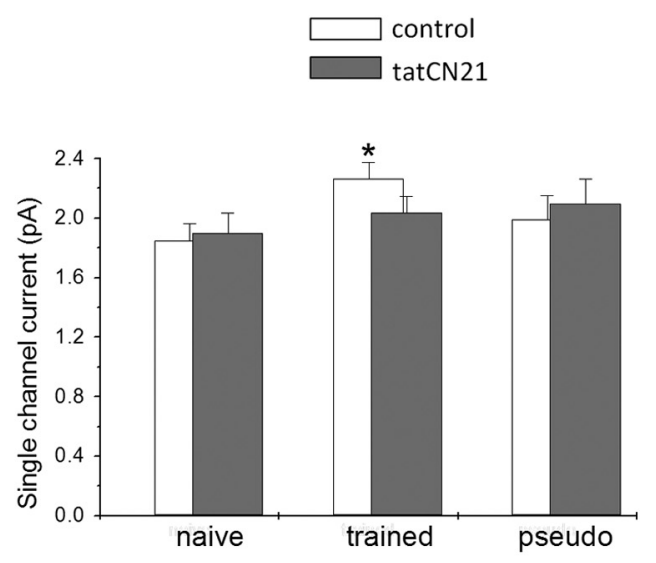

D

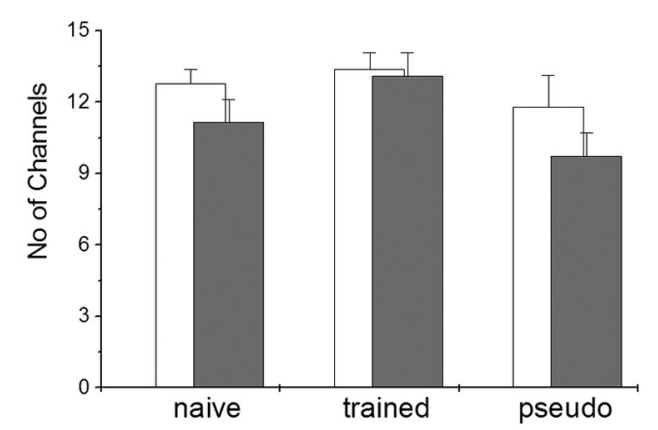

Figure 6. tatCN21 reduces the single GABA $A_{A}$ channel conductance in neurons from trained rats only. $A, B$, Current-variance plot extracted from the peak scaled mIPSCs before and after tatCN21 application. Examples from a pseudo-trained rat cell $(\boldsymbol{A})$ and a trained rat cell $(\boldsymbol{B})$ are shown. As evident from the initial slope of the parabola, tatCN21 reduced the single-channel current only in the trained neuron. $C$, The average $\mathrm{GABA}_{A}$ single-channel conductance is significantly reduced after drug application only for neurons from trained rats. Values represent the mean $\pm \mathrm{SE}\left({ }^{*} p<0.05\right)$. $D$, The average number of active $G A B A_{A}$ channels per event is not modified by drug application in the three groups. Average values were calculated using 5 cells taken from 5 naive rats, 10 cells taken from 8 trained rats, and 5 cells taken from 4 pseudo-trained rats.

from naive animals (14.2 \pm 3.6 in control conditions, $13.1 \pm 3.2$ with the peptide; $n=8)$ and from pseudo-trained rats $(15.3 \pm 1.3$ in control conditions, $14.5 \pm 1.6$ with the peptide; $n=7)$. As a result, the difference in the average mIPSC observed between the trained and the control groups was abolished after tatCN21 application (Fig. $5 A-C$ ). Here too, the effect of the peptide was most pronounced in neurons from trained rats (Fig. $5 D$ ). The inactive control peptide tatCtr (scrambled CN21;5 $\mu \mathrm{M}$ ) had no effect on the IPSC amplitudes [from $20.1 \pm 4.0$ to $19.6 \pm 2.7 \mathrm{pA}(n=6)$ in neurons from trained rats; and from $17.1 \pm 1.5$ to $17.3 \pm 1.5 \mathrm{pA}$ $(n=4)$ in neurons from control rats (two neurons from naive rats and two neurons from pseudo-trained rats)].

NSFA shows that such reduction in the average mIPSC in neurons from trained rats is mediated by a reduction of the average single-channel conductance (Fig. $6 A, B$ ); tatCN21 significantly reduced $\left(t_{(18)}=2.22, p<0.05\right)$ the single-channel conductance in neurons from trained rats (from $2.3 \pm 0.34$ to $2.03 \pm 0.35 \mathrm{pA}, n=10)$, while it had no effect on neurons from naive rats (from $1.85 \pm 0.25$ to $1.90 \pm 0.30 \mathrm{pA}, n=5$ ) and pseudo-trained rats (from $2.0 \pm 0.35$ to $1.81 \pm 2.01 \mathrm{pA}, n=5$ ). Subsequently, the difference in the average single-channel conductance between the groups disappeared (Fig. 6C). In contrast, the average number of channels activated by a spontaneous event was not affected by the drug application in neurons from the three groups [from $13.4 \pm 2.1$ to $13.1 \pm 3.3(n=10)$ in trained rats; from $12.8 \pm 1.3$ to $11.2 \pm 3.1(n=6)$ in naive rats; and from $11.8 \pm 3.5$ to $9.8 \pm 2.1(n=5)$ in pseudo-trained rats; Fig. $6 D]$.
PKC inhibition has a similar effect on neurons from trained and control rats

Application of the specific PKC blocker GF109203X (10 $\mu \mathrm{M})$ significantly reduced the average amplitude of the spontaneous inhibitory response in neurons from the three groups (Fig. 7A$C)$. In neurons from trained rats, the average value of the mIPSCs was reduced from $23.8 \pm 2.9$ to $17.8 \pm 2.6 \mathrm{pA}\left(t_{(8)}=7.75, p<\right.$ $0.001, n=9)$; in neurons from naive rats, from $17.9 \pm 3.7$ to $13.8 \pm 3.5 \mathrm{pA}\left(t_{(8)}=6.07, p<0.001, n=9\right)$; and in neurons from pseudo-trained rats, from $18.9 \pm 4.2$ to $14.7 \pm 4.0 \mathrm{pA}\left(t_{(9)}=3.64\right.$, $p<0.01, n=10)$. As shown in the example in Figure $7 B$, GF109203X reduced the amplitudes of events in all recorded neurons. Subsequently, the difference between the trained and the two control groups was maintained in the presence of the PKC blocker (Fig. 7C). The effect of the PKC blocker was apparent in most recorded neurons, regardless on the initial value of the average mIPSC (Fig. 7D).

NSFA shows that such reduction in the average mIPSC in neurons from the three groups is not mediated by reduction of the average single-channel conductance (Fig. 8A-C). The changes in average values in neurons from trained rats was similar before and after drug application [ from $2.34 \pm 0.33$ to $2.3 \pm$ $0.25 \mathrm{pA}(n=8)$; in naive rats, from $1.7 \pm 0.27$ to $1.78 \pm 0.55 \mathrm{pA}$ $(n=8)$; and in pseudo-trained rats, from $2.05 \pm 0.38$ to $2.0 \pm$ $0.58 \mathrm{pA}(n=8)]$.

Notably, the average number of channels activated by a spontaneous event was significantly reduced in neurons from the 
A

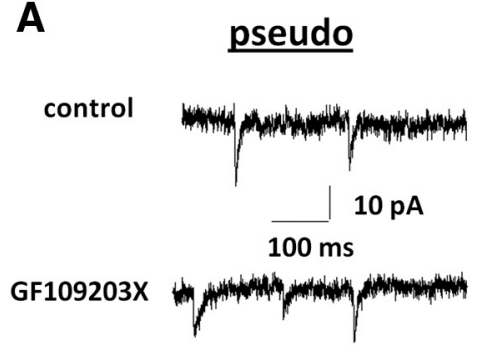

B
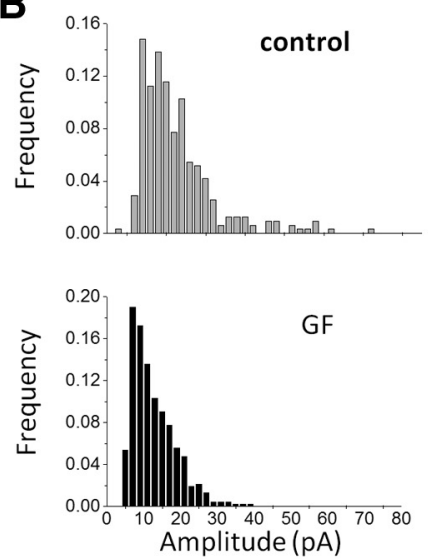
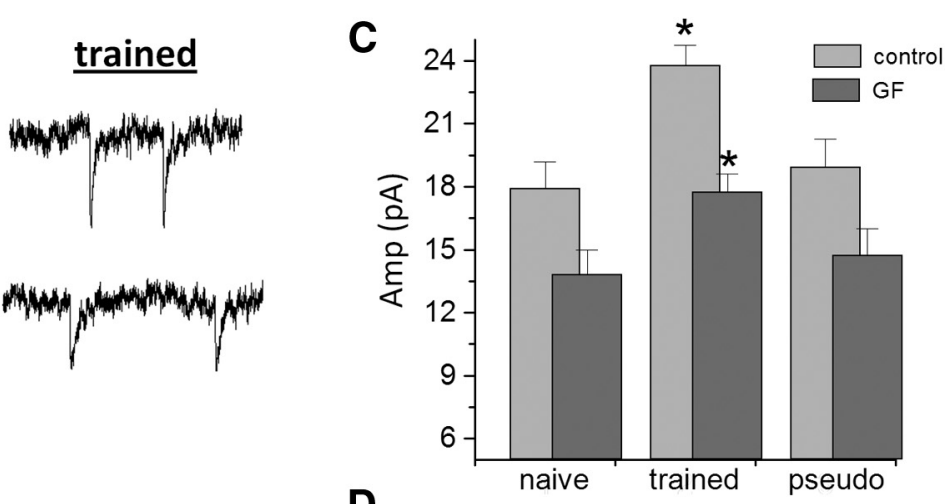

D

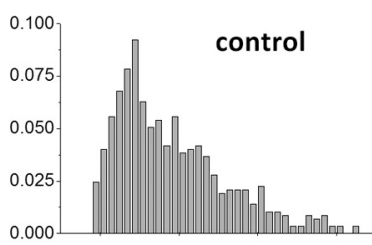

GF

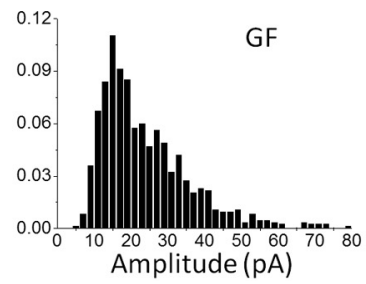

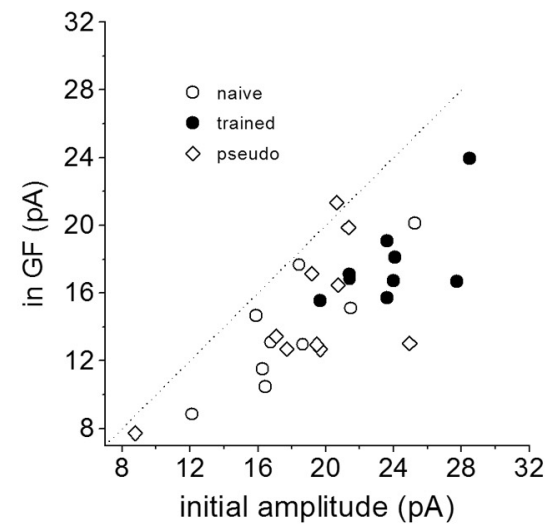

Figure 7. The effect of PKC inhibitor on the amplitudes of mIPSCs is not learning dependent. $A$, Spontaneous inhibitory events recorded from neurons from a pseudo-trained rat (left) and a trained rat (right), before (top traces) and after (bottom traces) application of the PKC blocker GF109203X. The amplitude of events is reduced in both neurons. $\boldsymbol{B}$, Amplitude histograms of the two neurons recorded in $\boldsymbol{A}$. GF109203X has a detectable effect on the amplitude distribution in the two neurons (bottom histograms). Note that amplitudes of all events, large and small, are affected. $\boldsymbol{C}$, The average amplitude if the inhibitory synaptic events is significantly reduced after GF109203X application in all three groups $\left({ }^{*} p<0.05\right)$, as a result of which the difference in the average amplitude among the groups remained. Data taken from three trained, four naïve, and four pseudo-trained rats. D, GF109203X reduces the amplitude of events in the three groups.

three groups [from $10.7 \pm 3.1$ to $8.2 \pm 0.9\left(t_{(6)}=3.26, p<0.05\right.$, $n=7)$ in trained rats; from $12.5 \pm 3.4$ to $7.6 \pm 2.1\left(t_{(6)}=2.39\right.$, $p<0.05, n=7)$ in naive rats; and from $11.1 \pm 2.7$ to $8.5 \pm 2.0$ $\left(t_{(5)}=4.4, p<0.01, n=6\right)$ in pseudo-trained rats; Fig. $8 D$ ]. Subsequently, the number of channels activated by an average mIPSC remained similar for the three groups.

PKA inhibition does not affect the average mIPSC amplitude in piriform cortex neurons

Application of the specific PKA blocker H89 dihydrochloride (50 $\mu \mathrm{M})$ did not affect the average mIPSC amplitudes of the spontaneous inhibitory response in neurons from the three groups (from $19.6 \pm 6.2$ to $18.9 \pm 7.9 \mathrm{pA}(n=16)$ in trained rats; from $15.3 \pm 3.4$ to $15.6 \pm 3.3 \mathrm{pA}(n=11)$ in naive rats; and from $14.5 \pm 3.5$ to $14.8 \pm 2.1 \mathrm{pA}(n=9)$ in pseudo-trained rats; Fig. 9). Notably, in the three groups PKA sometimes increased and sometimes decreased the mIPSC amplitude (Fig. 9D).

NSFA shows that the PKA blocker did not affect the single $\mathrm{GABA}_{\mathrm{A}}$ channel conductance in the three groups [from $2.1 \pm$ $0.77 \mathrm{pA}$ to $2.2 \pm 0.75 \mathrm{pA}(n=14)$ in trained rats; from $1.6 \pm 0.23$ to $1.6 \pm 0.31 \mathrm{pA}(n=9)$ in naive rats; and from $1.6 \pm 0.37$ to $1.7 \pm 0.27 \mathrm{pA}(n=9)$ in pseudo-trained rats; Fig. $10 A-C]$.

A similar lack of effect was found also for the number of channels activated by a single mIPSC (from $13.1 \pm 4.6$ to $13.5 \pm 4.4$ $(n=14)$ in trained rats; from $17.2 \pm 3.4$ to $16.6 \pm 3.3(n=9)$ in naive rats; and from $14.2 \pm 1.9$ to $13.6 \pm 2.5(n=9)$ in pseudotrained rats; Fig. 10D).

\section{Discussion}

The notion that learning-induced enhancement of synaptic transmission is not restricted to excitatory synaptic connections, but also requires strengthening of inhibition to prevent uncontrolled hyperexcitable activity has been long suggested (see for example, Golomb and Ermentrout, 2002). Indeed, a central role for synaptic inhibition in learning has been shown in several brain areas (Donato et al., 2013; Bañuelos et al., 2014; Courtin et al., 2014; Kfir et al., 2014; Sparta et al., 2014). The mechanisms underlying learning-induced and activity-induced plasticity of synaptic inhibition have been the subject of an increasing number of studies (Rivera et al., 2004; Fiumelli et al., 2005; Saar et al., 2012; McKay et al., 2013; Camiré and Topolnik, 2014; Kfir et al., 2014). We previously showed that complex olfactory learning results in long-lasting enhancement of $\mathrm{GABA}_{\mathrm{A}}$-mediated inhibitory synaptic transmission, which is widely spread throughout the piriform cortex pyramidal cell population, and is probably mediated via increased conductance of the $\mathrm{GABA}_{\mathrm{A}}$ channel (Saar et al., 2012; Reuveni et al., 2013). Here we explored the molecular mechanisms enabling such long-term enhancement.

\section{Learning-induced enhanced synaptic inhibition is mediated} by increased channel conductance

In a previous study, we applied NSFA to explore whether enhanced (excitatory and inhibitory) synaptic transmission is mediated by an increased number of channels or by the increased conductance of each channel (Reuveni et al., 2013). Our analysis 
A

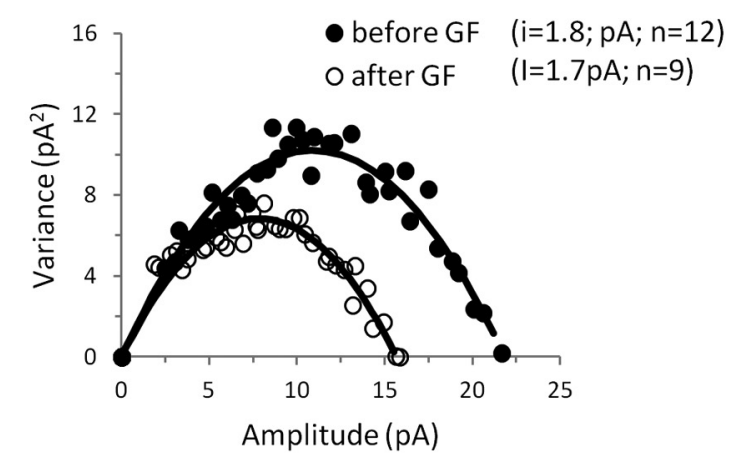

B

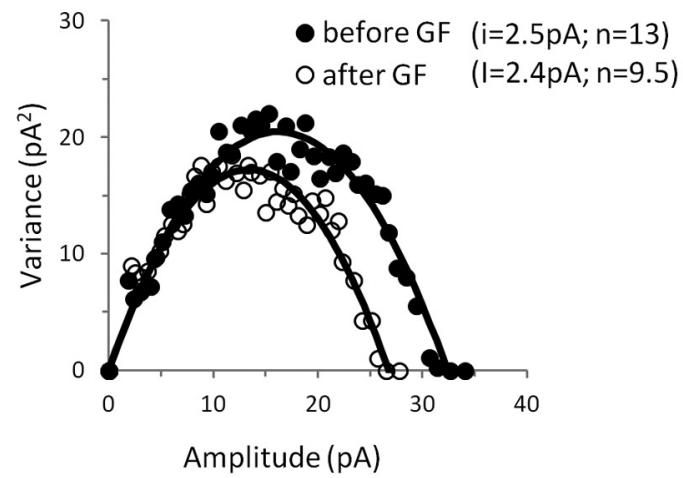

C

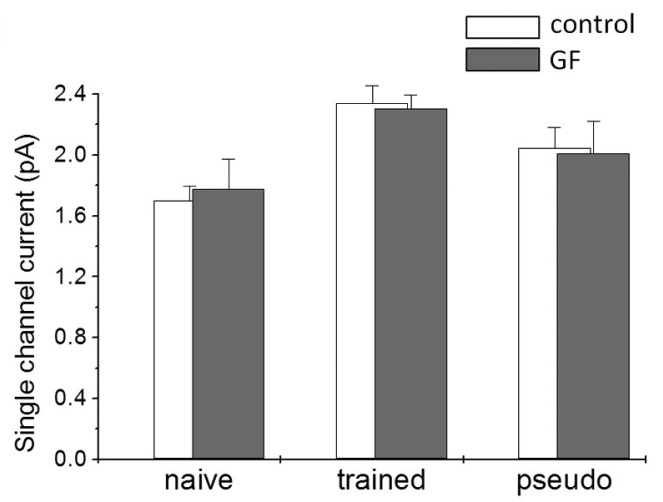

D

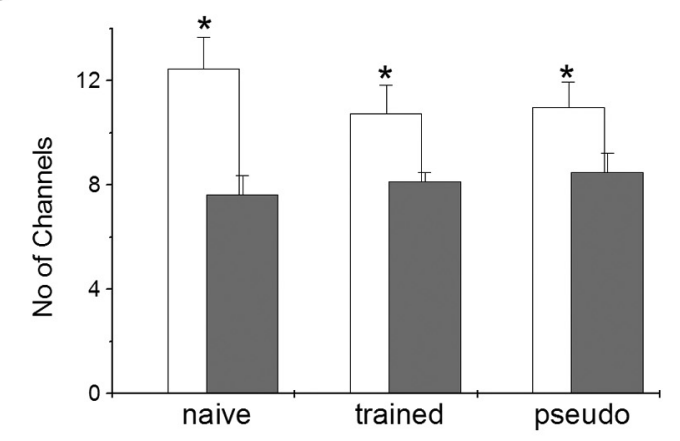

Figure 8. GF109203X reduces the number of activated GABA $A_{A}$ receptors in neurons from all groups. $A, B$, Current-variance plot extracted from the peak scaled mIPSCs before and after GF109203X application. Examples from a pseudo-trained rat cell $(\boldsymbol{A})$ and a trained rat cell $(\boldsymbol{B})$ are shown. GF109203X reduced the number of activated channels in the two neurons and did not modify the single-channel current, as is evident from the similarity in the initial slope. $C$, The average $G_{B B} A_{A}$ single-channel conductance is not modified after drug application in the three groups. $\boldsymbol{D}$, The average number of active $\mathrm{GABA}_{A}$ channels per event is significantly lower in all groups after drug application. Values represent the mean $\pm \mathrm{SE}\left({ }^{*} p<0.05\right)$. Average values were calculated using eight cells taken from three naive rats, eight cells taken from three trained rats, and eight cells taken from three pseudo-trained rats.

showed that the latter is correct. Here we repeated the analysis using a much larger sample of neurons. Our results confirm the previous study; all of the increases in the amplitudes of the spontaneous mIPSCs can be attributed to increased channel conductance. NSFA also shows that the number of $\mathrm{GABA}_{\mathrm{A}}$ channels opened during each inhibitory synaptic event is not modified after learning. This conclusion is supported by the biochemical analysis showing that the expression level of three key $\mathrm{GABA}_{\mathrm{A}}$ receptor subunits, $\beta 2, \beta 3$, and $\gamma 2$, is not modified after learning. We thus explored the mechanism by which such enhanced channel conductance is maintained for days after learning.

Several key second-messenger systems, such as CaMKII, PKC, and PKA, are implicated both in inhibitory plastic processes and in the modulation of the $\mathrm{GABA}_{\mathrm{A}}$ channel conductance and surface expression (Houston et al., 2009; Luscher et al., 2011). These proteins have been long shown to have phosphorylation sites on the $\beta 2, \beta 3$, and $\gamma 2$ subunits (McDonald and Moss, 1997; Houston et al., 2009).

Learning-induced enhancement of $\mathrm{GABA}_{\mathrm{A}}$-mediated synaptic inhibition is mediated by persistent CaMKII activation

Our data show that blocking of CaMKII reduces the singlechannel conductance in neurons from trained rats to pretraining level, while showing no effect on neurons from the two control groups. This learning-specific effect, which abolishes completely the difference between mIPSCs in neurons from trained and untrained rats, strongly suggests that persistent CaMKII-dependent phosphorylation is the mechanism by which fast synaptic inhibition is maintained at an enhanced state for days after learning. In addition, CaMKII does not affect the number of activated channels.

CaMKII has been long suggested to have a key role in synaptic plasticity and learning (Elgersma and Silva, 1999; Lisman et al., 2002; Redondo et al., 2010; Sanhueza at el., 2011). Long-term potentiation (LTP) is mediated by CaMKII phosphorylation, which, once it is activated by calcium/calmodulin, persists in its activity after the calcium concentration returns to the baseline level (Miller and Kennedy, 1986). CaMKII produces potentiation of excitatory synaptic transmission by phosphorylation of the AMPA receptor subunits in a synapse-specific manner (Lisman et al., 2012). In later stages of LTP, CaMKII augments the sizes of spines and has a role in spine stabilization (Hell, 2014). Later studies also implicated CaMKII in long-term synaptic depression (Mockett et al., 2011; Coultrap et al., 2014).

CaMKII has also been suggested to have a role in inhibition (Kano et al., 1996). CaMKII is translocated selectively to inhibitory synapses in response to moderate NMDA receptor activation (Marsden et al., 2010), as a result of which inhibitory transmission is potentiated (Marsden et al., 2007). A detailed study, performed in hippocampal neurons in culture, showed that CaMKII phosphorylation on Ser383 within the $\beta 3$ subunit results in an increased cell surface expression of the receptor (Saliba et al., 2012). This result seems not to agree with our findings that CaMKII is required for maintaining enhanced single-channel conductance and does not affect the number of channels. However, this study examined the effect of CaMKII within minutes of activation. We studied a long-term effect, which is maintained for days after the last training session. Thus, it may 
A

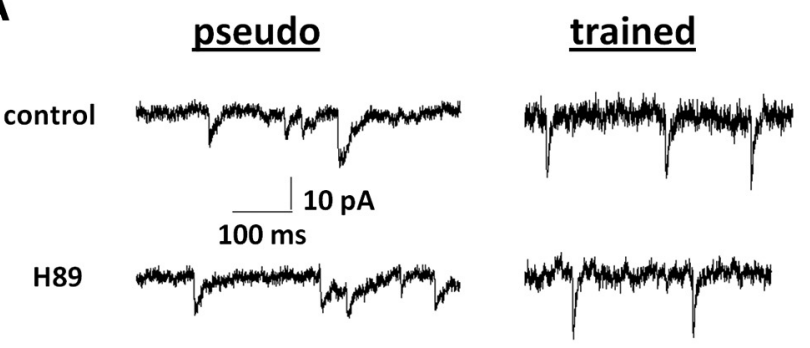

B
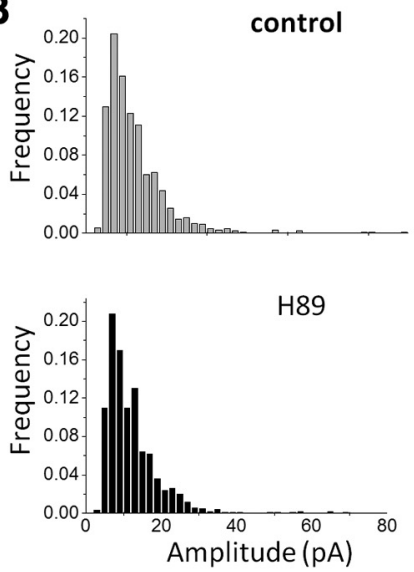

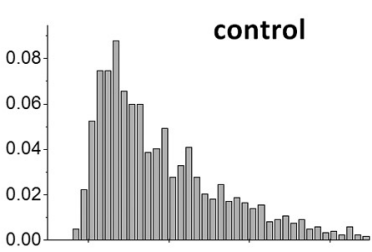

H89

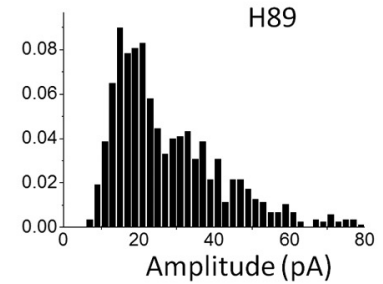

C

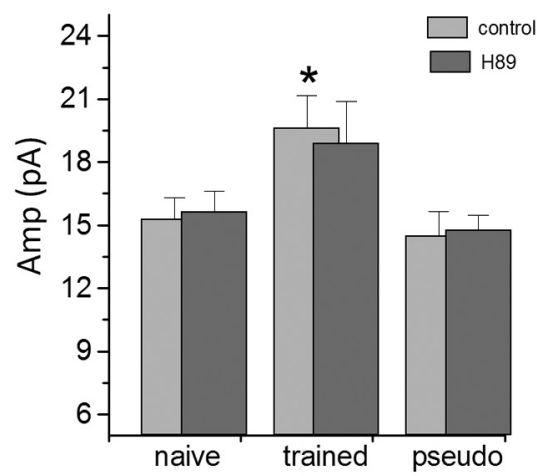

D

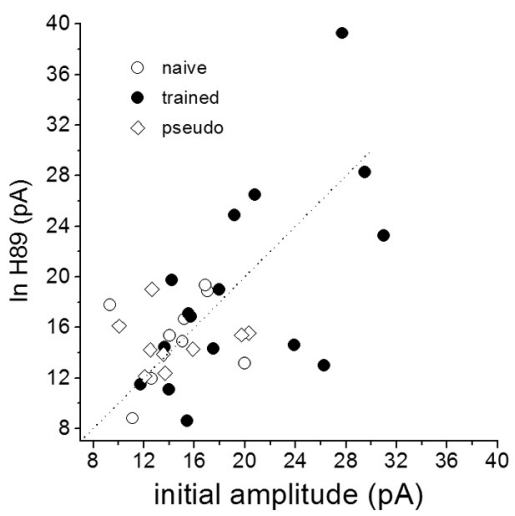

Figure 9. PKA inhibition does not affect the average mIPSCs amplitude in pyramidal neurons from all groups. $\boldsymbol{A}$, Spontaneous inhibitory events recorded from neurons from a pseudo-trained rat (left) and a trained rat (right), before (top traces) and after (bottom traces) application of the PKC blocker H89 dihydrochloride. The amplitude of events in both neurons is not modified by the blocker. $\boldsymbol{B}$, Amplitude histograms of the two neurons recorded in $\boldsymbol{A}$. $\mathrm{H} 89$ dihydrochloride does not have a notable effect on the amplitude distribution in the two neurons (bottom histograms). $\boldsymbol{C}$, The average amplitude if the inhibitory synaptic events is not modified in the three groups, and the learning-induced increase in the average amplitude remains $\left({ }^{*} p<0.05\right)$. Data taken from eight trained, seven naïve, and six pseudo-trained rats. $\boldsymbol{D}$, Although $\mathrm{H} 89$ dihydrochloride modifies the amplitudes of events in the three groups, it appears to have a bidirectional effect, as a result of which no net change occurs in the average values.

well be possible that the short-term and long-term effects of CaMKII on the $\mathrm{GABA}_{\mathrm{A}}$ channel are mediated by two different mechanisms.

\section{PKC affects the number of activated channels in a} non-learning-dependent manner

Blocking PKC resulted in an equal reduction in the number of spontaneous inhibitory events in neurons from all experimental groups, as a result of which the difference in the average amplitude between the trained group and the two control groups remained. Notably, at the concentration used (10 $\mu \mathrm{M})$ GF109203X is an efficient blocker of all PKC isoforms. NSFA suggests that such a decrease is the result of a reduction in the number of channels activated in each event.

Previous studies suggest that $\mathrm{PKC}$ regulates the $\mathrm{GABA}_{\mathrm{A}}$ receptor function by reducing synaptic response, with no effect on the number of the surface-expressed receptors (Krishek et al., 1994; Brandon et al., 2000). Thus, our results in this study suggest that the long-term effects of PKC on inhibitory synaptic conductance are different from the early effects (within minutes of activation) reported in those previous studies. Notably, another more recent study reported that $\mathrm{PKC}$ positively regulates insertion of the $\mathrm{GABA}_{\mathrm{A}}$ receptor into the membrane (Abramian et al., 2010). These results well agree with our findings. et al., 2011), blocking PKA activity seem to have no net effect on single-channel conductance or on the number of activated channels in neurons from the three experimental groups. Notably, PKA did affect the amplitudes of the spontaneous inhibitory events in the three groups. However, it sometimes enhanced and sometimes reduced the amplitudes (Fig. 9D), as result of which its average effect was zero. Thus, unlike CaMKII and PKC, the effect of PKA on the amplitudes of mIPSCs is not consistent in all neurons.

One possible explanation for this phenomenon can be found in the finding that PKA can differentially regulate the $\mathrm{GABA}_{\mathrm{A}}$ receptor by phosphorylating different sites on different isoforms of $\beta 3$ subunits (McDonald et al., 1998). It would be of great interest to further explore a possible role for PKA in modulating learning-relevant modifications in $\mathrm{GABA}_{\mathrm{A}}$ receptor activation.

Relation to the role of second-messenger systems in maintaining learning-induced modulation of intrinsic neuronal excitability

We have previously shown that key second-messenger systems have a role not only in learning-relevant synaptic plasticity, but also in maintaining learning-induced enhancement of neuronal excitability (Seroussi et al., 2002; Cohen-Matsliah et al., 2007; Liraz at al., 2009). These studies show that learning-induced enhanced intrinsic excitability is mediated by persistent PKC activation, which results in reduced slow calcium-dependent potassium current conductance, and thus with enhanced repetitive 
A

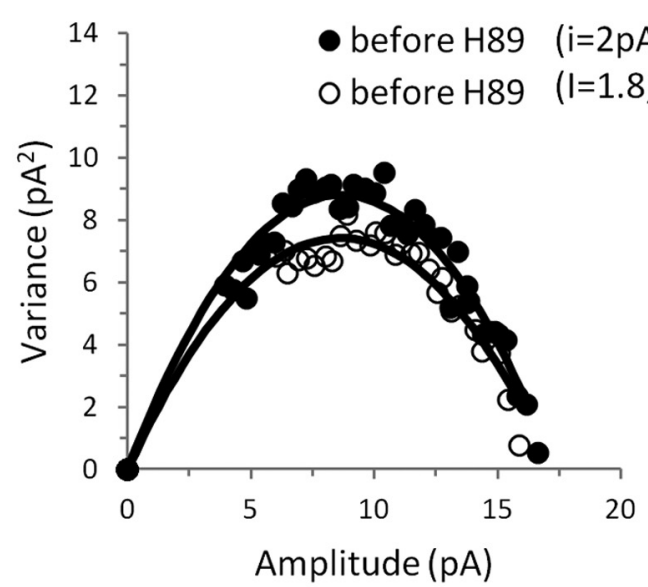

B

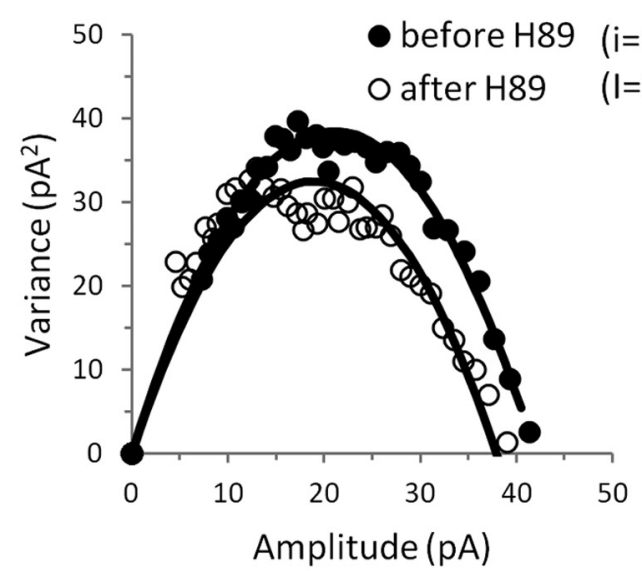

C

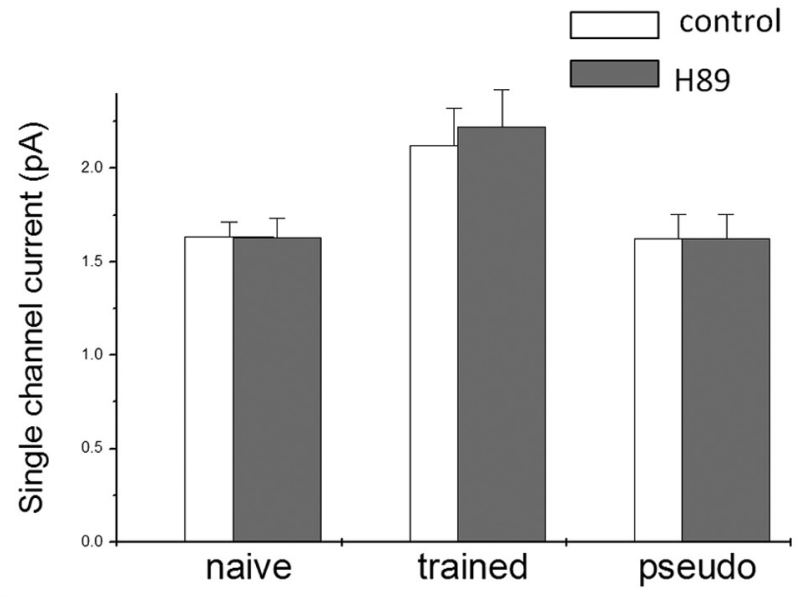

D

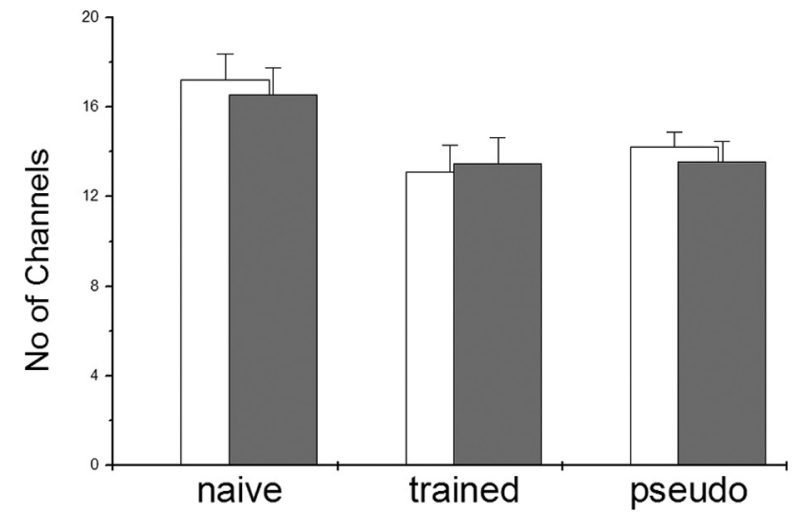

Figure 10. H89 dihydrochloride does not modify the average $\mathrm{GABA}_{\mathrm{A}}$ single-channel conductance or the number of activated channels. $\boldsymbol{A}, \boldsymbol{B}, \mathrm{Current}-\mathrm{variance}$ plot extracted from the peak scaled mIPSCs before and after $\mathrm{H} 89$ dihydrochloride application. Examples from a pseudo-trained rat cell $(\boldsymbol{A})$ and a trained rat cell $(\boldsymbol{B})$ are shown. In these examples, H89 dihydrochloride does not affect the single-channel current or the number of activated channels in the two neurons. $\boldsymbol{C}$, The average $\mathrm{GABA}_{\mathrm{A}}$ single-channel conductance is not modified by the PKA blocker in the three groups. $\boldsymbol{D}$, The average number of spontaneous events activated by $\mathrm{GABA}_{\mathrm{A}}$ channels is not modified by the drug in the three groups. Average values were calculated using 9 cells taken from 8 naive rats, 15 cells taken from 10 trained rats, and 9 cells taken from 6 pseudo-trained rats.

spike firing (Seroussi et al., 2002; Cohen-Matsliah et al., 2007). While PKA and CaMKII also regulate the same current, this regulation is not modified by learning. Thus, it appears that different second-messenger systems that regulate the maintenance of learning-induced long-lasting physiological modifications do so by affecting different physiological manifestations of the neuronal response.

In conclusion, our study shows that complex olfactory discrimination learning-induced enhancement of the fast inhibitory synaptic response is enabled by CaMKII-dependent persistent enhancement of the $\mathrm{GABA}_{\mathrm{A}}$ channel conductance in most pyramidal neurons in the piriform cortex.

\section{References}

Abramian AM, Comenencia-Ortiz E, Vithlani M, Tretter EV, Sieghart W, Davies PA, Moss SJ (2010) Protein kinase C phosphorylation regulates membrane insertion of GABAA receptor subtypes that mediate tonic inhibition. J Biol Chem 285:41795-41805. CrossRef Medline

Bañuelos C, Beas BS, McQuail JA, Gilbert RJ, Frazier CJ, Setlow B, Bizon JL (2014) Prefrontal cortical GABAergic dysfunction contributes to age-related working memory impairment. J Neurosci 34:3457-3466. CrossRef Medline

Benke TA, Lüthi A, Isaac JT, Collingridge GL (1998) Modulation of AMPA receptor unitary conductance by synaptic activity. Nature 393:793-797. CrossRef Medline
Brandon NJ, Delmas P, Kittler JT, McDonald BJ, Sieghart W, Brown DA, Smart TG, Moss SJ (2000) GABAA receptor phosphorylation and functional modulation in cortical neurons by a protein kinase C-dependent pathway. J Biol Chem 275:38856-38862. CrossRef Medline

Brosh I, Barkai E (2009) Learning-induced enhancement of feedback inhibitory synaptic transmission. Learn Mem 16:413-416. CrossRef Medline

Buard I, Coultrap SJ, Freund RK, Lee YS, Dell'Acqua ML, Silva AJ, Bayer KU (2010) CaMKII "autonomy" is required for initiating but not for maintaining neuronal long-term information storage. J Neurosci 30:82148220. CrossRef Medline

Camiré O, Topolnik L (2014) Dendritic calcium nonlinearities switch the direction of synaptic plasticity in fast-spiking interneurons. J Neurosci 34:3864-3877. CrossRef Medline

Cohen-Matsliah SI, Brosh I, Rosenblum K, Barkai E (2007) A novel role for ERK in maintaining long-term memory-relevant excitability changes. J Neurosci 27:12584-12589. CrossRef Medline

Coultrap SJ, Freund RK, O'Leary H, Sanderson JL, Roche KW, Dell'Acqua ML, Bayer KU (2014) Autonomous CaMKII mediates both LTP and LTD using a mechanism for differential substrate site selection. Cell Rep 6:431-437. CrossRef Medline

Courtin J, Chaudun F, Rozeske RR, Karalis N, Gonzalez-Campo C, Wurtz H, Abdi A, Baufreton J, Bienvenu TC, Herry C (2014) Prefrontal parvalbumin interneurons shape neuronal activity to drive fear expression. Nature 505:92-96. CrossRef Medline

Donato F, Rompani SB, Caroni P (2013) Parvalbumin-expressing basket- 
cell network plasticity induced by experience regulates adult learning. Nature 504:272-276. CrossRef Medline

Elgersma Y, Silva AJ (1999) Molecular mechanisms of synaptic plasticity and memory. Curr Opin Neurobiol 9:209-213. CrossRef Medline

Fiumelli H, Cancedda L, Poo MM (2005) Modulation of GABAergic transmission by activity via postsynaptic $\mathrm{Ca} 2+$-dependent regulation of $\mathrm{KCC} 2$ function. Neuron 48:773-786. CrossRef Medline

Golomb D, Ermentrout GB (2002) Slow excitation supports propagation of slow pulses in networks of excitatory and inhibitory populations. Phys Rev E Stat Nonlin Soft Matter Phys 65:061911. CrossRef Medline

Grunze HC, Rainnie DG, Hasselmo ME, Barkai E, Hearn EF, McCarley RW, Greene RW (1996) NMDA-dependent modulation of CA1 local circuit inhibition. J Neurosci 16:2034-2043. Medline

Hasselmo ME, Barkai E (1995) Cholinergic modulation of activitydependent synaptic plasticity in the piriform cortex. J Neurosci 15:65926604. Medline

Hell JW (2014) CaMKII: claiming center stage in postsynaptic function and organization. Neuron 81:249-265. CrossRef Medline

Holmgren CD, Zilberter Y (2001) Coincident spiking activity induces longterm changes in inhibition of neocortical pyramidal cells. J Neurosci 21: 8270-8277. Medline

Houston CM, He Q, Smart TG (2009) CaMKII phosphorylation of the GABA(A) receptor: receptor subtype- and synapse-specific modulation. J Physiol 587:2115-2125. CrossRef Medline

Jasinska M, Siucinska E, Cybulska-Klosowicz A, Pyza E, Furness DN, Kossut M, Glazewski S (2010) Rapid, learning-induced inhibitory synaptogenesis in murine barrel field. J Neurosci 30:1176-1184. CrossRef Medline

Kano M, Kano M, Fukunaga K, Konnerth A (1996) Ca(2+)-induced rebound potentiation of gamma-aminobutyric acid-mediated currents requires activation of $\mathrm{Ca} 2+/$ calmodulin-dependent kinase II. Proc Natl Acad Sci U S A 93:13351-13356. CrossRef Medline

Kfir A, Ohad-Giwnewer N, Jammal L, Saar D, Golomb D, Barkai E (2014) Learning-induced modulation of the GABAB-mediated inhibitory synaptic transmission. J Neurophysiol 111:2029-2038. CrossRef Medline

Knafo S, Libersat F, Barkai E (2005) Dynamics of learning-induced spine redistribution along dendrites of pyramidal neurons. Eur J Neurosci 21: 927-935. CrossRef Medline

KomatsuY, Yoshimura Y (2000) Activity-dependent maintenance of longterm potentiation at visual cortical inhibitory synapses. J Neurosci 20: 7539-7546. Medline

Krishek BJ, Xie X, Blackstone C, Huganir RL, Moss SJ, Smart TG (1994) Regulation of GABAA receptor function by protein kinase $\mathrm{C}$ phosphorylation. Neuron 12:1081-1095. CrossRef Medline

Ling DS, Benardo LS, Sacktor TC (2006) Protein kinase Mzeta enhances excitatory synaptic transmission by increasing the number of active postsynaptic AMPA receptors. Hippocampus 16:443-452. CrossRef Medline

Liraz O, Rosenblum K, Barkai E (2009) CAMKII activation is not required for maintenance of learning-induced enhancement of neuronal excitability. PLoS One 4:e4289. CrossRef Medline

Lisman J, Schulman H, Cline H (2002) The molecular basis of CaMKII function in synaptic and behavioural memory. Nat Rev Neurosci 3:175190. CrossRef Medline

Lisman J, Yasuda R, Raghavachari S (2012) Mechanisms of CaMKII action in long-term potentiation. Nat Rev Neurosci 13:169-182. CrossRef Medline

Luscher B, Fuchs T, Kilpatrick CL (2011) GABAA receptor trafficking-mediated plasticity of inhibitory synapses. Neuron 70:385-409. CrossRef Medline

Lüthi A, Wikström MA, Palmer MJ, Matthews P, Benke TA, Isaac JT, Collingridge GL (2004) Bi-directional modulation of AMPA receptor unitary conductance by synaptic activity. BMC Neurosci 5:44. CrossRef Medline

Marsden KC, Beattie JB, Friedenthal J, Carroll RC (2007) NMDA receptor activation potentiates inhibitory transmission through GABA receptorassociated protein-dependent exocytosis of $\mathrm{GABA}_{\mathrm{A}}$ receptors. J Neurosci 27:14326-14337. CrossRef Medline

Marsden KC, Shemesh A, Bayer KU, Carroll RC (2010) Selective translocation of $\mathrm{Ca} 2+/$ calmodulin protein kinase IIalpha (CaMKIIalpha) to inhibitory synapses. Proc Natl Acad Sci U S A 107:20559-20564. CrossRef Medline

McDonald BJ, Moss SJ (1997) Conserved phosphorylation of the intracellular domains of GABA(A) receptor beta2 and beta3 subunits by cAMPdependent protein kinase, cGMP-dependent protein kinase protein kinase $\mathrm{C}$ and $\mathrm{Ca} 2+/$ calmodulin type II-dependent protein kinase. Neuropharmacology 36:1377-1385. CrossRef Medline

McDonald BJ, Amato A, Connolly CN, Benke D, Moss SJ, Smart TG (1998)
Adjacent phosphorylation sites on GABAA receptor beta subunits determine regulation by cAMP-dependent protein kinase. Nat Neurosci 1998: 23-28. Medline

McKay BM, Oh MM, Disterhoft JF (2013) Learning increases intrinsic excitability of hippocampal interneurons. J Neurosci 33:5499-5506. CrossRef Medline

Miller SG, Kennedy MB (1986) Regulation of brain type II Ca2+/ calmodulin-dependent protein kinase by autophosphorylation: a Ca2+triggered molecular switch. Cell 44:861-870. CrossRef Medline

Mockett BG, Guévremont D, Wutte M, Hulme SR, Williams JM, Abraham WC (2011) Calcium/calmodulin-dependent protein kinase II mediates group I metabotropic glutamate receptor-dependent protein synthesis and long-term depression in rat hippocampus. J Neurosci 31:7380-7391. CrossRef Medline

Ohba S, Ikeda T, Ikegaya Y, Nishiyama N, Matsuki N, Yamada MK (2005) BDNF locally potentiates GABAergic presynaptic machineries: targetselective circuit inhibition. Cereb Cortex 15:291-298. CrossRef Medline

Redondo RL, Okuno H, Spooner PA, Frenguelli BG, Bito H, Morris RG (2010) Synaptic tagging and capture: differential role of distinct calcium/ calmodulin kinases in protein synthesis-dependent long-term potentiation. J Neurosci 30:4981-4989. CrossRef Medline

Reuveni I, Saar D, Barkai E (2013) A novel whole-cell mechanism for longterm memory enhancement, PLoS One 8:e68131. CrossRef

Rivera C, Voipio J, Thomas-Crusells J, Li H, Emri Z, Sipilä S, Payne JA, Minichiello L, Saarma M, Kaila K (2004) Mechanism of activitydependent downregulation of the neuron-specific $\mathrm{K}-\mathrm{Cl}$ cotransporter KCC2. J Neurosci 24:4683-4691. CrossRef Medline

Saar D, Grossman Y, Barkai E (1998) Reduced after-hyperpolarization in rat piriform cortex pyramidal neurons is associated with increased learning capability during operant conditioning. Eur J Neurosci 10:1518-1523. CrossRef Medline

Saar D, Grossman Y, Barkai E (1999) Reduced synaptic facilitation between pyramidal neurons in the piriform cortex after odor learning. J Neurosci 19:8616-8622. Medline

Saar D, Grossman Y, Barkai E (2001) Long lasting cholinergic modulation underlies rule learning in rats. J Neuorsci 21:1385-1392.

Saar D, Grossman Y, Barkai E (2002) Learning-induced enhancement of postsynaptic potentials in pyramidal neurons. J Neurophysiol 87:2358-2363. Medline

Saar D, Reuveni I, Barkai E (2012) Mechanisms underlying high-skill learning-induced enhancement of excitatory and inhibitory synaptic transmission. J Neurophysiol 107:1222-1229. CrossRef Medline

Saliba RS, Kretschmannova K, Moss SJ (2012) Activity-dependent phosphorylation of GABAA receptors regulates receptor insertion and tonic current. EMBO J 31:2937-2951. CrossRef Medline

Sanhueza M, Fernandez-Villalobos G, Stein IS, Kasumova G, Zhang P, Bayer KU, Otmakhov N, Hell JW, Lisman J (2011) Role of the CaMKII/ NMDA receptor complex in the maintenance of synaptic strength. J Neurosci 31:9170-9178. CrossRef Medline

Scelfo B, Sacchetti B, Strata P (2008) Learning-related long-term potentiation of inhibitory synapses in the cerebellar cortex. Proc Natl Acad Sci U S A 105:769-774. CrossRef Medline

Seroussi Y, Brosh I, Barkai E (2002) Learning-induced reduction in postburst after-hyperpolarization (AHP) is mediated by activation of PKC. Eur J Neurosci 16:965-969. CrossRef Medline

Sparta DR, Hovelsø N, Mason AO, Kantak PA, Ung RL, Decot HK, Stuber GD (2014) Activation of prefrontal cortical parvalbumin interneurons facilitates extinction of reward-seeking behavior.J Neurosci34:3699-3705. CrossRefMedline

Staubli U, Fraser D, Faraday R, Lynch G (1987) Olfaction and the "data" memory system in rats. Behav Neurosci 101:757-765. CrossRef Medline

Studniarczyk D, Coombs I, Cull-Candy SG, Farrant M (2013) TARP $\gamma-7$ selectively enhances synaptic expression of calcium-permeable AMPARs. Nat Neurosci 16:1266-1274. CrossRef Medline

Suzuki N, Bekkers JM (2007) Inhibitory interneurons in the piriform cortex. Clin Exp Pharmacol Physiol 34:1064-1069. CrossRef Medline

Suzuki N, Bekkers JM (2010) Distinctive classes of GABAergic interneurons provide layer-specific phasic inhibition in the anterior piriform cortex. Cereb Cortex 20:2971-2984. CrossRef Medline

Yang Y, Tao-Cheng JH, Bayer KU, Reese TS, Dosemeci A (2013) Camkiimediated phosphorylation regulates distributions of Syngap- $\alpha 1$ and $-\alpha 2$ at the postsynaptic density. PLoS One 8:e71795. CrossRef Medline

Zelcer I, Cohen H, Richter-Levin G, Lebiosn T, Grossberger T, Barkai E (2006) A cellular correlate of learning-induced metaplasticity in the hippocampus. Cereb Cortex 16:460-468. CrossRef Medline 